\title{
Carbon-nitrogen interactions regulate climate-carbon cycle feedbacks: results from an atmosphere-ocean general circulation model
}

\author{
P. E. Thornton ${ }^{1}$, S. C. Doney ${ }^{2}$, K. Lindsay ${ }^{3}$, J. K. Moore ${ }^{4}$, N. Mahowald ${ }^{5}$, J. T. Randerson ${ }^{4}$, I. Fung ${ }^{6}$, \\ J.-F. Lamarque ${ }^{7,8}$, J. J. Feddema ${ }^{9}$, and Y.-H. Lee ${ }^{3}$ \\ ${ }^{1}$ Environmental Sciences Division, Oak Ridge National Laboratory, Oak Ridge, TN 37831-6335, USA \\ ${ }^{2}$ Department of Marine Chemistry and Geochemistry, Woods Hole Oceanographic Institution, Woods Hole, \\ MA 02543-1543, USA \\ ${ }^{3}$ Climate and Global Dynamics Division, National Center for Atmospheric Research, Boulder, CO 80307-3000, USA \\ ${ }^{4}$ Department of Earth System Science, University of California, Irvine, CA 92697-3100, USA \\ ${ }^{5}$ Department of Earth and Atmospheric Sciences, Cornell University, Ithaca, NY 14850, USA \\ ${ }^{6}$ Department of Earth and Planetary Science, University of California, Berkeley, CA 94720-4767, USA \\ ${ }^{7}$ NOAA Earth System Research Laboratory, Chemical Sciences Division, 325 Broadway, Boulder, CO 80305-3337, USA \\ ${ }^{8}$ Atmospheric Chemistry Division, National Center for Atmospheric Research, Boulder, CO 80307-3000, USA \\ ${ }^{9}$ Department of Geography, University of Kansas, Lawrence, KS 66045-7613, USA
}

Received: 28 January 2009 - Published in Biogeosciences Discuss.: 26 March 2009

Revised: 12 August 2009 - Accepted: 17 September 2009 - Published: 8 October 2009

\begin{abstract}
Inclusion of fundamental ecological interactions between carbon and nitrogen cycles in the land component of an atmosphere-ocean general circulation model (AOGCM) leads to decreased carbon uptake associated with $\mathrm{CO}_{2}$ fertilization, and increased carbon uptake associated with warming of the climate system. The balance of these two opposing effects is to reduce the fraction of anthropogenic $\mathrm{CO}_{2}$ predicted to be sequestered in land ecosystems. The primary mechanism responsible for increased land carbon storage under radiatively forced climate change is shown to be fertilization of plant growth by increased mineralization of nitrogen directly associated with increased decomposition of soil organic matter under a warming climate, which in this particular model results in a negative gain for the climate-carbon feedback. Estimates for the land and ocean sink fractions of recent anthropogenic emissions are individually within the range of observational estimates, but the combined land plus ocean sink fractions produce an airborne fraction which is too high compared to observations. This bias is likely due in part to an underestimation of the ocean sink fraction. Our results show a significant growth in the airborne fraction of anthropogenic $\mathrm{CO}_{2}$ emissions over the coming
\end{abstract}

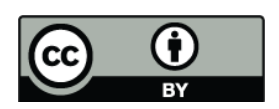

Correspondence to: P. E. Thornton (thorntonpe@ornl.gov) century, attributable in part to a steady decline in the ocean sink fraction. Comparison to experimental studies on the fate of radio-labeled nitrogen tracers in temperate forests indicates that the model representation of competition between plants and microbes for new mineral nitrogen resources is reasonable. Our results suggest a weaker dependence of net land carbon flux on soil moisture changes in tropical regions, and a stronger positive growth response to warming in those regions, than predicted by a similar AOGCM implemented without land carbon-nitrogen interactions. We expect that the between-model uncertainty in predictions of future atmospheric $\mathrm{CO}_{2}$ concentration and associated anthropogenic climate change will be reduced as additional climate models introduce carbon-nitrogen cycle interactions in their land components.

\section{Introduction}

Climate change over the next several centuries will depend on anthropogenic emissions of carbon dioxide as well as feedbacks between climate and the carbon cycle (Meehl et al., 2007). All previously published modeling studies of the climate-carbon cycle feedback based on atmosphere-ocean general circulation models (AOGCMs) have found that climate warming driven by greenhouse gas accumulation in the

Published by Copernicus Publications on behalf of the European Geosciences Union. 
atmosphere causes a net release or reduced uptake of carbon dioxide from both land and oceans, contributing to a positive feedback that enhances radiatively-forced climate change (Matthews et al., 2007; Friedlingstein et al., 2006). These studies, however, have not included an explicit treatment of nutrient dynamics within land ecosystems.

Carbon uptake in land ecosystems depends on the availability of nutrients such as nitrogen to support new growth, and fertilization studies show that the availability of mineral nitrogen limits primary production in many natural and managed ecosystems (Elser et al., 2007; Vitousek and Howarth, 1991; LeBauer and Treseder, 2008). On an annual basis, the large majority of nitrogen in new plant growth derives from the decomposition of plant litter and soil organic matter, resulting in a strong coupling in which heterotrophic respiration depends on the organic matter produced by plants, and plant growth depends on the mineral nitrogen released from organic mater during decomposition (Vitousek and Howarth, 1991; Melillo et al., 2002). Nitrogen limitation is also expected to become more pronounced in some ecosystems as atmospheric $\mathrm{CO}_{2}$ concentration $\left(C_{a}\right)$ increases (the "progressive nitrogen limitation" hypothesis) (Luo et al., 2004, 2006; Reich et al., 2006).

Recent modeling results obtained by introducing prognostic carbon and nitrogen cycle interactions in the stand-alone land-surface component of an AOGCM (Thornton et al., 2007) or in a reduced-complexity climate model (Sokolov et al., 2008) suggest that the land-atmosphere components of the global climate-carbon cycle feedback are fundamentally influenced by carbon-nitrogen cycle $(\mathrm{C}-\mathrm{N})$ interactions. Thornton et al. (2007) used a land-surface component of a climate model in an uncoupled mode, forced by a reanalysis of historical surface weather, to demonstrate that C-N interactions significantly reduce the stimulation of net carbon uptake on land associated with increased $C_{a}$. This reduces a negative feedback in the regulation of $C_{a}$, and should lead to higher $C_{a}$ for a given level of fossil fuel consumption in a coupled climate-carbon cycle simulation. A significant reduction in simulated land ecosystem $\mathrm{CO}_{2}$ fertilization with the introduction of $\mathrm{C}-\mathrm{N}$ dynamics was also reported by Sokolov et al. (2008). These two previous studies (Thornton et al., 2007; Sokolov et al., 2008) predict a 53-78\% reduction of the effect of elevated $\mathrm{CO}_{2}$ on land carbon sink strength due to $\mathrm{C}-\mathrm{N}$ coupling.

Thornton et al. (2007) also showed that C-N interaction fundamentally alters the land carbon cycle response to interannual variability in temperature and precipitation, suggesting that $\mathrm{C}-\mathrm{N}$ coupling would also affect the land carbon cycle response to transient changes in temperature and precipitation. Sokolov et al. (2008) did not examine the variability issue, but found that the introduction of $\mathrm{C}-\mathrm{N}$ coupling in a reduced-complexity climate model produced a change in the sign of the terrestrial carbon cycle response to warming, switching from a strong positive feedback in which warming leads to a net release of carbon from the terrestrial biosphere, to a weak negative feedback in which warming leads to a modest uptake of carbon.

The positive feedback predicted by Sokolov et al. (2008) using the carbon-only version of their model is consistent with previous results using carbon-only models, in which radiatively-forced warming drives a net transfer of carbon from both land and oceans to the atmosphere (Matthews et al., 2007; Friedlingstein et al., 2006). For land, this positive feedback has been attributed to an increase in soil organic matter decomposition and the sensitivity of plant growth (primary production) to both soil moisture status (Fung et al., 2005) and temperature (Matthews et al., 2007). Previous models include the direct dependence of decomposition on plant growth, through the supply of litter, but neglect the dependence of plant growth on nutrient availability (Doney et al., 2006). This leads to an incongruous representation of the carbon cycle feedback response to warming, by including the direct influence of warming on respiration and photosynthesis, while ignoring the influence of warming on the mineralization of nutrients stored in decomposing organic matter and the potential for increased nutrient availability to stimulate plant growth under conditions of nutrient limitation (Melillo et al., 2002).

In the present study we expand on earlier results by introducing a prognostic representation of terrestrial carbon and nitrogen cycles within a fully-coupled AOGCM. This coupling provides the opportunity to examine the interactions among changes in land and ocean carbon pools, changes in $C_{a}$ and mineral nitrogen deposition as forced by fossilfuel consumption, and radiatively-forced transient changes in temperature and precipitation. In addition to framing our study within a full-complexity climate model, the current work improves on the analysis of Sokolov et al. (2008) by employing a land C-N model with prognostic nitrogen inputs and outputs, including inputs from biological nitrogen fixation and losses due to prognostic wildfire, as opposed to a specified nitrogen stock for each gridbox (Fig. 1). We use this model to evaluate land carbon and nitrogen cycle responses to three factors: response to climate change driven by radiative coupling with prognostic $C_{a}$ (denoted $\Delta_{C C}$ ); response to anthropogenic mineral nitrogen deposition (denoted $\Delta_{N D}$ ); and direct physiological response to increasing $C_{a}$ (denoted $\Delta_{C a}$ ). We assess the influence of these interactions on the sign and magnitude of climate-carbon cycle feedback parameters.

The influence of C-N coupling on carbon cycle dynamics is sensitive to the partitioning of nitrogen between low $\mathrm{C}: \mathrm{N}$ ratio pools such as soil organic matter and high $\mathrm{C}: \mathrm{N}$ ratio pools such as wood (Hungate et al., 2003; Nadelhoffer et al., 1999; Nadelhoffer et al., 2004; McGuire et al., 2001). As a preliminary step toward establishing confidence in the modeled C-N interactions, a comparison of modeled and measured nitrogen cycle dynamics in the context of labeledtracer fertilization studies is also presented. 


\section{Methods}

Our study uses a modified version of the Community Climate System Model (CCSM), which includes ocean biogeochemistry and ecosystem dynamics (Moore et al., 2004), and coupled terrestrial carbon and nitrogen cycles (Thornton and Zimmermann, 2007). Using four global simulations we isolate the effects $\Delta_{C C}, \Delta_{N D}$, and $\Delta_{C a}$, including corrections for differences between simulations in $C_{a}$ (Friedlingstein et al., 2006). Simulations are all 230 years in length, covering the nominal time period 1870 to 2099. Fossil fuel emissions are specified identically for each simulation based on observations for the historical period and following a business-asusual scenario for future emissions. Fossil fuel, land, and ocean carbon fluxes provide boundary conditions for $\mathrm{CO}_{2}$ tracers in the atmosphere, resulting in a time-evolving (prognostic) $C_{a}$ as a tracer which responds to all of these fluxes. Atmospheric radiative forcing responds either to this prognostic $C_{a}$ or to a specified preindustrial value (radiatively coupled and uncoupled experiments, respectively). Mineral nitrogen deposition from the atmosphere to the land surface is forced either by a transient dataset consistent with prescribed fossil fuel emissions (Lamarque et al., 2005), or by a constant-in-time preindustrial dataset. In all cases land and ocean carbon fluxes respond to the prognostic $C_{a}$.

\subsection{Detailed methods}

\subsubsection{Model description}

Our study uses a version of the Community Climate System Model (CCSM) modified to include a prognostic carbon cycle, ocean biogeochemistry and ecosystem dynamics, and coupled terrestrial carbon and nitrogen cycles. Modifications were applied to CCSM version 3.0 (Collins et al., 2006), using the low-resolution version of the model (Yeager et al., 2006) to reduce computational cost associated with the lengthy spin-up simulations.

Modifications to the land component (Community Land Model version 3) (Dickinson et al., 2006) include: the introduction of prognostic carbon and nitrogen cycles for canopy dynamics, accompanied by a new canopy integration scheme that improves the representation of sunlit and shaded canopy fractions (Thornton and Zimmermann, 2007); prognostic carbon and nitrogen cycles for the litter and soil (Thornton and Rosenbloom, 2005); coupling of plant-litter-soil carbon and nitrogen cycles (Thornton et al., 2007; Thornton and Rosenbloom, 2005); and several changes to the hydrologic sub-model to improve partitioning of evapotranspiration (Lawrence et al., 2007). Detailed process descriptions for the carbon and nitrogen cycle components are available (Thornton et al., 2007). The resulting land component is referred to as the Community Land Model with coupled Carbon and Nitrogen cycles (CLM-CN).

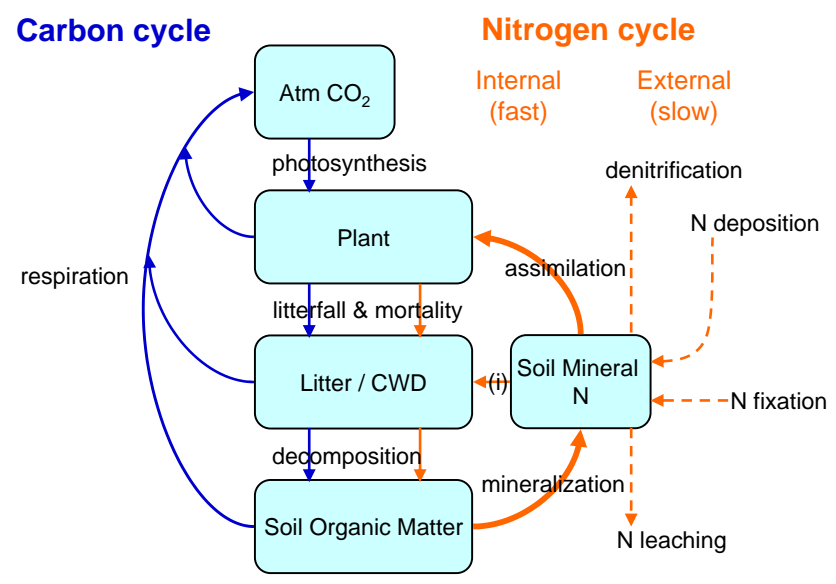

Fig. 1. Schematic illustrating feedback pathways coupling terrestrial carbon and nitrogen cycles in CLM-CN. Blue arrows show, in general, the processes represented in previous carbon-only land model components: plant carbon uptake by photosynthesis draws down atmospheric carbon dioxide $\left(\mathrm{Atm} \mathrm{CO}_{2}\right)$; litterfall and plant mortality pass biomass from plant to litter and coarse woody debris (CWD); decomposition of fresh litter generates soil organic matter; respiration by both plants and heterotrophic organisms returns $\mathrm{CO}_{2}$ to the atmosphere. Orange arrows show the additional processes represented in our coupled carbon-nitrogen land model, differentiated here between rapid internal cycling (solid arrows), and slower fluxes between land pools, the atmosphere, and ground water (dashed arrows). The critical feedback pathway connecting heterotrophic respiration with plant growth is highlighted as a thick orange arrow: decomposition of soil organic matter not only releases $\mathrm{CO}_{2}$ to the atmosphere, it also releases nitrogen from the organic matter (mineralization) in forms that can then be taken up by plants (assimilation). Plant nitrogen uptake competes with the demand for mineral nitrogen from heterotrophic organisms decomposing fresh litter (immobilization, abbreviated (i) in the Fig.).

Modification to the ocean component of CCSM3 includes incorporation of the Biogeochemical Elemental Cycling (BEC) model, with multiple phytoplankton functional groups (diatoms, diazotrophs, smaller phytoplankton, and coccolithophores) and multiple potentially growth-limiting nutrients (nitrate, ammonium, phosphate, silicate, and iron) (Moore et al., 2002, 2004). The model allows for variable $\mathrm{Fe} / \mathrm{C}$ and $\mathrm{Si} / \mathrm{C}$ ratios dependent on ambient nutrient availability. The ecosystem is coupled with a carbonate chemistry module based on the Ocean Carbon Model Intercomparison Project (OCMIP) (Doney et al., 2003, 2004), allowing dynamic computation of surface ocean $p \mathrm{CO}_{2}$ and air-sea $\mathrm{CO}_{2}$ flux. The vertical profile of shortwave radiation absorption in the ocean model is determined by the prognostic chlorophyll distribution from the BEC model.

\subsubsection{Experimental design}

The primary purpose of our study is to demonstrate the sensitivity of a fully-coupled AOGCM to interactions between 
Table 1. Simulation organization and naming convention. All simulations start from steady-state carbon cycle in year 1870, and all simulations include the same prescribed trajectory of fossil fuel emissions, creating a time-evolving $C_{a}$. All simulations include the direct physical and biological response of land and oceans to the time-evolving $C_{a}$, but only the radiatively-coupled experiments $(R N$ and $R n)$ experience the greenhouse effect of rising $C_{a}$ on radiative forcing in the atmosphere.

\begin{tabular}{llcc}
\hline \multicolumn{1}{c}{ Simulation naming convention } & \multicolumn{2}{c}{$\begin{array}{c}\text { Atmospheric mineral nitrogen } \\
\text { deposition }\end{array}$} \\
\cline { 2 - 4 } & & $\begin{array}{c}\text { Anthropogenic } \\
\text { (transient) }\end{array}$ & $\begin{array}{c}\text { Preindustrial } \\
\text { (fixed) }\end{array}$ \\
\hline Radiative effects of & Prognostic $C_{a}$ & $R N$ & $R n$ \\
\cline { 2 - 4 } atmospheric $\mathrm{CO}_{2}$ & Prescribed $(287.0 \mathrm{ppm})$ & $r N$ & $r n$ \\
\hline
\end{tabular}

carbon and nutrient cycling, with a particular focus on the degree to which those interactions influence the global carbon cycle. Our experimental design focuses on two distinct aspects of the overall carbon-climate interaction: response of land ecosystems to radiatively-forced climate change (warming and changes in precipitation patterns), and land ecosystem response to direct fertilization of growth from increasing $C_{a}$ and increasing nitrogen deposition.

One potential approach to quantifying the C-N interaction is to perform two separate sets of simulations, one with fully-dynamic C-N interactions and the other using a C-only model configuration. This strategy was used by Thornton et al. (2007) to explore the influence of $\mathrm{C}-\mathrm{N}$ coupling of $\mathrm{CO}_{2}$ and nitrogen fertilization of land carbon uptake, and also by Sokolov et al. (2008). A disadvantage of that approach is that the inclusion or exclusion of $\mathrm{C}-\mathrm{N}$ dynamics produces very different conditions for the pre-industrial steady-state control simulations. This difference in base states complicates the interpretation and attribution of differences in the transient ecosystem responses to $C_{a}$ and to radiatively forced climate change. Thornton et al. (2007) used multiple C-only simulations to constrain this problem, which for an offline simulation was not prohibitively expensive in terms of computation time.

We introduce here a new approach which eliminates all concerns about differences in base state, while still illuminating the differences between $\mathrm{C}$-only and $\mathrm{C}-\mathrm{N}$ dynamics most critical to the interactions with changing surface climate, $C_{a}$, and nitrogen deposition. In addition to the $\mathrm{N}$ saturation mechanism used in Thornton et al. (2007) to emulate the behavior of a C-only model, CLM-CN also includes (on every time step, at every grid cell, and for every sub-grid vegetation type) a calculation of the potential gross primary production (GPP) that could occur in the absence of nutrient limitation, given the ecosystem state at that point in time. The calculation of potential GPP is used in conjunction with a dynamic allocation algorithm to express the plant demand for new mineral N. Following the calculation of mineral N supply and the $\mathrm{N}$ demand of microbial communities, plantmicrobe competition is reconciled and an actual GPP is calculated, reflecting the influence of $\mathrm{N}$ limitation. Differences between potential and actual GPP are driven exclusively by the dynamics of $\mathrm{N}$ availability, while every other physical and biogeochemical aspect of the land model simulation is maintained in an identical state.

Following model spinup to preindustrial steady-state conditions (details in Sect. 2.1.3), a long (1000-year) preindustrial control simulation was performed, during which the climate as well as ocean and land carbon and nitrogen cycles were stable (unpublished results). The control simulation was followed by four simulation experiments. All experiments include prescribed fossil fuel emissions, using historical data for the period 1870-1999 with modifications from a previously published dataset (Andres et al., 1996), and emissions from the SRES A2 scenario for the period 2000-2099 (Nakicenovic and Swart, 2000). Revisions of the historical emissions data were performed by Andres (unpublished), and include updates for the period 1990-2003, and modifications for one degree geography and raw carbon emissions data for earlier years.

In all experiments fossil fuel, land, and ocean carbon fluxes provide boundary conditions for $\mathrm{CO}_{2}$ tracers in the atmosphere, where $C_{a}$ is a tracer which responds to all of these fluxes. Land and ocean carbon fluxes in all cases respond to this prognostic $C_{a}$. Calculations of radiative transfer in the atmosphere respond either to the prognostic $C_{a}$ ("radiatively coupled" experiments) or to a fixed preindustrial value ("radiatively uncoupled" experiments). Experiments also differ in their treatment of nitrogen deposition, using either a transient dataset that represents the anthropogenic influence or a fixed preindustrial distribution. Organization and naming conventions for the four experiments are given in Table 1.

Inclusion of simulations with and without anthropogenic nitrogen deposition serves three purposes. First, it provides a basis for evaluation of carbon cycle sensitivity to anthropogenic nitrogen inputs. Second, it serves as a simple metric for evaluating the hypothesis that radiatively forced climate change affects land ecosystems in a manner similar to direct mineral $\mathrm{N}$ fertilization. Third, it provides an opportunity to assess the magnitude of the modeled land carbon uptake response to new nitrogen inputs against observations and experimental metrics. 
All simulations for this study use a constant representation of land cover (see Sect. 2.5), and so also exclude the representation of carbon fluxes associated with changes in land cover or land use. Previous coupled climate-carbon cycle simulations with AOGCMs have also used constant land use patterns but have specified assumed fluxes due to land use and land cover change (LULCC) as external forcing (Friedlingstein et al., 2006). Imposing LULCC fluxes as an external forcing factor ignores interactions among disturbance, $\mathrm{CO}_{2}$ fertilization, and nitrogen availability known to influence modeled net carbon flux responses (Thornton et al., 2002). Here we are interested in addressing the C-N interactions in the absence of potentially confounding anthropogenic disturbance effects. We recognize that this experimental design hampers direct comparison of our results to measured $C_{a}$, and we have tried to mitigate this problem by focusing evaluation efforts on land, ocean, and airborne fractions (see Sect. 2.6).

\subsubsection{Model spinup}

To reduce the magnitude of drifts in the carbon pools when carbon and nitrogen are coupled to the climate of the AOGCM, a sequential spin-up procedure is employed, similar to a previously described procedure (Doney et al., 2006). The land carbon components are spun-up to an approximate preindustrial steady-state, using a repeated 25-year cycle of near-surface weather fields saved from a previous coupled simulation. Initial spinup of carbon and nitrogen pools in the land model follows the accelerated decomposition approach described in Thornton and Rosenbloom, 2005. Surface forcing for the initial ocean spinup is from an observationally based climatology (Large and Yeager, 2004), with $C_{a}$ held at a fixed preindustrial value. The ocean spinup was run for 1000 years with no tracer acceleration.

Land and ocean states following preliminary spinup simulations are not necessarily in balance with the climate of the fully-coupled system. A fully-coupled simulation (Sim0) is performed for a few hundred years to get past any initial transients, to assess the potentially offsetting fluxes between land, atmosphere, and ocean, and to generate a climatology of $C_{a}$ for use in subsequent coupling steps.

Several incremental coupling steps are performed to bring the system efficiently to a stable initial condition. First, a coupled run is done where $C_{a}$ is allowed to vary, but is only forced by air-sea $\mathrm{CO}_{2}$ fluxes (Sim1). This enables the negative feedback between air-sea $\mathrm{CO}_{2}$ fluxes and $C_{a}$, effectively shortening the equilibration time of the ocean. For the present simulations, the 150 -year running mean of the air-sea $\mathrm{CO}_{2}$ flux was less than $0.01 \mathrm{PgCy}^{-1}$ after 450 years in this configuration. Next, the land model is run again in an offline configuration (Sim2), using a repeated 25-year cycle of near-surface weather fields saved from Sim1. Sim2 uses the climatology of $C_{a}$ from $\operatorname{Sim} 0$, adjusted to have the same over-ocean mean to which the ocean is equilibrated in
Sim1. Sim2 is run until the land state is equilibrated with the new sample of coupled climate and the new climatology of $C_{a}$ (1800 years in the present case). The land state from Sim2 and the ocean state from Sim1 are next used to initiate a new coupled run (Sim3), with $C_{a}$ responding to both land and ocean fluxes, but with atmospheric radiative forcing responding to a specified (preindustrial) $\mathrm{CO}_{2}$ concentration. After 200 years, atmospheric radiative forcing is allowed to respond to the prognostic $C_{a}$.

\subsection{Evaluation of forcing factors}

Our experiments are analyzed to isolate the effects of radiatively-forced climate change, anthropogenic nitrogen deposition, and increasing $C_{a}\left(\Delta_{C C}, \Delta_{N D}\right.$, and $\Delta_{C a}$, respectively). In calculating $\Delta_{C C}$ and $\Delta_{N D}$, we correct for differences in $C_{a}$ between pairs of experiments, following the "beta-correction" method (Friedlingstein et al., 2003, 2006). For a generic flux or state variable time series, $f(t)$ :

$$
\begin{aligned}
& \Delta_{C C} f(t)=\left(f_{\text {coupled }}(t)-f_{\text {uncoupled }}(t)\right) \\
& -\beta_{f}\left(C_{a, \text { coupled }}(t)-C_{a, \text { uncoupled }}(t)\right)
\end{aligned}
$$

where $f_{\text {coupled }}(t)$ and $C_{a \text {,coupled }}(t)$ are from experiment $R n$, $f_{\text {uncoupled }}(t)$ and $C_{a \text {,uncoupled }}(t)$ are from experiment $r n$, and $\beta_{f}$ is the dependence of $f$ on $C_{a}\left(\mathrm{~d} f / \mathrm{d} C_{a}\right)$ from a radiatively-uncoupled experiment. Likewise, for $\Delta_{N D}$ :

$$
\begin{aligned}
& \Delta_{N D} f(t)=\left(f_{\text {anthro } N D}(t)-f_{\operatorname{preind} N D}(t)\right) \\
& -\beta_{f}\left(C_{a, \text { anthro } N D}(t)-C_{a, \text { preind } N D}(t)\right)
\end{aligned}
$$

where $f_{\text {anthro } N D}$ and $C_{a \text {,anthro } N D}$ are from experiment $r N$, and $f_{\text {preind } N D}$ and $C_{a \text {,preind } N D}$ are from experiment $r n$. In practice, we calculate $\beta_{f}$ as the regression slope of the time series $f(t)$ vs. $C_{a}(t)$ from experiment $r n$.

Time series of effects on carbon fluxes due to increasing $C_{a}$ are calculated as:

$\Delta_{C a} f(t)=\left(f_{F F}(t)-f_{F F, 0}\right)$

where $f_{F F}(t)$ is from a radiatively uncoupled simulation with prescribed fossil fuel emissions (our experiment $r n$ ), and $f_{F F, 0}$ is the mean flux from the first decade of experiment $r n$, when fossil fuel fluxes are very small. Combined effects of $\Delta_{C C}, \Delta_{N D}$, and $\Delta_{C a}$ are evaluated as the change over time in simulation $R N$, by subtracting the mean of the first decade of simulation from the entire time series.

\subsection{Temperature and soil moisture effects on land carbon fluxes}

For each grid cell, multiple linear regression is used to evaluate the partial contributions of changing near-surface air temperature over land $\left(T_{\text {air }}\right)$ and changing soil moisture on several land carbon flux components. Soil moisture is expressed as an empirical moisture scalar, $B_{\text {tran }}$, with values ranging from 0 to 1 (Oleson et al., 2004). We calculate $\Delta_{C C} f$, the 
influence of radiatively forced climate change for flux component $f$, as well as the influence of radiative coupling on $T_{\text {air }}\left(\Delta_{C C} T_{\text {air }}\right)$ and $B_{\text {tran }}\left(\Delta_{C C} B_{\text {tran }}\right)$ using Eq. (1). The time series of $\Delta_{C C} f$ is regressed against time series of $\Delta_{C C} T_{\text {air }}$ and $\Delta_{C C} B_{\text {tran }}$, using annual values for the period 2000$2099(n=100)$. Flux components $(f)$ evaluated include potential gross primary production (potential GPP), defined as the model-estimated GPP prior to nitrogen limitation, actual $G P P$, defined as model-estimated GPP following the calculation of nitrogen limitation, total ecosystem respiration $(E R)$, fire (total carbon loss to atmosphere during combustion), and net ecosystem exchange of carbon $(N E E=-G P P+E R+$ fire $)$.

\subsection{Transient feedback analysis}

We use the analytical framework for diagnosis of climatecarbon cycle feedback as presented in Friedlingstein et al. (2003, 2006), but modified to allow an examination of transients in feedback parameters. An endpoint analysis was used by Friedlingstein et al. (2006), where single summary values of the feedback parameters were based on differences between the values of carbon and temperature state variables at the beginning and end of their simulations. This provided a single estimate of the feedback parameter values, applicable to the entire simulation period. Here we are interested also in the temporal variation in the feedback parameters, so we use a somewhat different method and compare results to those obtained with the original method by Friedlingstein et al. (2006). For our transient analysis, we use a moving window, unweighted regression to calculate the relevant slopes. At each annual timestep $t$, where $t \geq 120$, the previous 120 years of data from the global summaries is used as input to a least-squares regression $(n=120)$ to estimate the feedback parameters at time $t$ as the regression slopes. All other aspects of the analysis are as described previously (Friedlingstein et al., 2003, 2006), including the use of simulation differencing to isolate the effects of increasing $C_{a}$ and radiatively-forced climate change on carbon uptake. Overall climate-carbon cycle feedback strength, denoted gain (unitless) is defined as:

$\operatorname{gain}=-\alpha\left(\gamma_{L}+\gamma_{O}\right) /\left(1+\beta_{L}+\beta_{O}\right)$

where $\alpha\left(\mathrm{K} \mathrm{ppm}^{-1}\right)$ is the transient sensitivity of the climate model to increased $C_{a}, \beta_{L}$ and $\beta_{O}\left(\mathrm{PgC} \mathrm{ppm}^{-1}\right)$ are the carbon storage sensitivities to $C_{a}$ for land and ocean, respectively, and $\gamma_{L}$ and $\gamma_{O}\left(\mathrm{PgC} \mathrm{K}^{-1}\right)$ are the carbon storage sensitivities to climate for land and ocean, respectively. The following expressions are used to calculate components of gain, following Friedlingstein et al. (2003, 2006):

$$
\begin{aligned}
& \alpha=\frac{\mathrm{d} T_{\text {ref_coupled }}}{\mathrm{d} C_{a_{-} \text {coupled }}}, \\
& \beta_{L}=\frac{\mathrm{dTot} C_{L_{-} \text {uncoupled }}}{\mathrm{d} C_{a_{-} \text {uncoupled }}} \text { and } \beta_{O}=\frac{\mathrm{dTot} C_{O_{-} \text {uncoupled }}}{\mathrm{d} C_{a_{-} \text {uncoupled }}},
\end{aligned}
$$

$$
\gamma_{L}=\frac{\mathrm{dTot} C_{L_{-} \text {coupled }}^{*}}{\mathrm{~d} T_{\text {ref_coupled }}} \text { and } \gamma_{O}=\frac{\mathrm{dTot} C_{O \_ \text {coupled }}^{*}}{\mathrm{~d} T_{\text {ref_coupled }}},
$$

$\operatorname{Tot} C_{L_{-} \text {coupled }}^{*}=\operatorname{Tot} C_{L_{-} \text {coupled }}-\beta_{L}$

$\left(C_{a_{-} \text {coupled }}-C_{a_{\_} \text {uncoupled }}\right)$ and $\operatorname{Tot} C_{O \_ \text {coupled }}^{*}$

$=$ Tot $C_{O_{-} \text {coupled }}-\beta_{O}\left(C_{a_{-} \text {coupled }}-C_{a_{-} \text {uncoupled }}\right)$

where $T_{\text {ref_coupled }}$ and $C_{a_{-} \text {coupled }}$ are the global mean air temperature at the model reference height $(\mathrm{K})$ and the global mean $C_{a}(\mathrm{ppm})$, respectively, from a radiatively coupled experiment, $C_{a_{-} \text {uncoupled }}(\mathrm{ppm})$ is the global mean $C_{a}$ from a radiatively uncoupled experiment, Tot $C_{L_{-} \text {uncoupled }}$ and Tot $C_{O}$ _uncoupled $(\mathrm{PgC})$ are the global total carbon content on land and in oceans, respectively, for a radiatively uncoupled

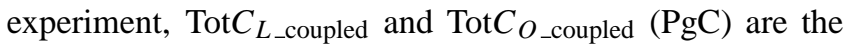
global total carbon content on land and in oceans, respectively, for a radiatively coupled experiment, and the notation $\frac{\mathrm{d} y}{\mathrm{~d} x}$ refers to the slope from the moving window regression of $y$ against $x$, as described above.

A positive value for gain corresponds to a net (ocean and land) positive climate-carbon cycle feedback by which warming stimulates carbon release and an increase in $C_{a}$ which increases warming, while a negative value of gain corresponds to a negative net feedback by which warming stimulates uptake and a decrease in $C_{a}$ which suppresses warming. Analysis of previously published modeling results used archived annual global summaries of output from the eleven models included in the recent C4MIP synthesis (Friedlingstein et al., 2006) (http://www.c4mip.cnrs-gif.fr/ diagnostics_phase2.html).

\subsection{Treatment of landcover}

All results reported here use a fixed description of landcover, taken as a time slice circa 1870 from a transient plant functional type (PFT) dataset. The transient PFT dataset is created in two steps. First, a potential vegetation PFT dataset is created based on information about present-day PFT distribution and estimates of potential biome types of vegetation (Ramankutty and Foley, 1999). Second, estimates of crop land fraction (Ramankutty and Foley, 1999) and grazing (Goldewijk, 2001) are used to determine the crop PFT distribution through time. It is important to note that because our present simulations have prescribed landcover for the year 1870, they do not include the effects of changing landcover on carbon, nitrogen, water, or energy fluxes. Additional simulations are underway to evaluate the influence of changing landcover on carbon fluxes and $\mathrm{C}-\mathrm{N}$ interactions.

\subsection{Airborne fraction, land sink fraction, and ocean sink fraction}

Following the nomenclature and methods in Raupach et al. (2008), we calculate an annual total airborne fraction of 
anthropogenic emissions $\left(a_{E}\right)$ as the annual change in the carbon stock of the atmosphere expressed as a fraction of the annual total anthropogenic emissions. For our simulations emissions due to land use and land cover change are assumed to be zero, and the anthropogenic emissions consist only of fossil fuel sources. Land and ocean sink fractions $\left(s_{E, \text { Ind }}\right.$ and $s_{E, \text { ocn }}$, respectively) are calculated as the annual changes in total land or ocean carbon stocks as fractions of the annual total anthropogenic emissions. Growth rates for the airborne fraction $\left(r\left(a_{E}\right)\right)$, land sink fraction $\left(r\left(s_{E, \text { lnd }}\right)\right)$, and ocean sink fraction $\left(r\left(s_{E, \text { ocn }}\right)\right)$, expressed as $\%$ change per year, are calculated as the regression slopes of the log-transformed time series.

\subsection{Nitrogen deposition}

Nitrogen deposition rates for the period 1870 to 2100 are from the three-dimensional chemistry-transport MOZART-2 (Model for Ozone and Related Tracers, version 2) (Horowitz et al., 2003). In all simulations (pre-industrial, present-day and future), MOZART uses meteorological datasets valid for the period of interest, based on simulations by the Parallel Climate Model (Washington et al., 2000). The MOZART2 simulations are performed at a horizontal resolution of $2.8^{\circ}$. All the dynamical and chemical processes simulated by MOZART-2 are performed with a model timestep of $20 \mathrm{~min}$, while the nitrogen deposition fluxes are archived as monthly averages. Additional information on the present-day and future simulations is available (Lamarque et al., 2005). The pre-industrial simulation is similar to the present-day simulations, except that all emissions associated with anthropogenic activities (excluding biomass burning) are explicitly set to 0 . Nitrogen deposition from the MOZART-2 preindustrial simulation is used for the CLM-CN spin-up simulation.

\subsection{Fate of additional N}

The anthropogenic $\mathrm{N}$ deposition experiment (experiment $r N$, Table 1) provides an opportunity to evaluate the modeled fate of new mineral $\mathrm{N}$ additions against results of ${ }^{15} \mathrm{~N}$ tracer experiments. By quantifying and evaluating the fate of added $\mathrm{N}$, we are also able to assess whether the model predictions of carbon storage associated with increases in soil organic matter (low $\mathrm{C}: \mathrm{N}$ ratio) or increases in wood (high $\mathrm{C}: \mathrm{N}$ ) follow observed patterns. The influence of $\mathrm{N}$ deposition was diagnosed by tracking the changes in $\mathrm{N}$ storage in land ecosystem pools as well as cumulative fluxes into and out of the land ecosystem. Results were compared with observations from a ${ }^{15} \mathrm{~N}$ tracer study carried out at Harvard Forest (Nadelhoffer et al., 2004) by extracting information from the nearest point in the global grid. Coordinates of the study site are $42^{\circ} 30^{\prime} \mathrm{N}$, $72^{\circ} 10^{\prime} \mathrm{W}$. Center coordinates for the model grid box containing this site are $42^{\circ} 41^{\prime} \mathrm{N}, 71^{\circ} 15^{\prime} \mathrm{W}$, and the dimensions of the grid box at this location are $3.71^{\circ}$ latitude $\times 3.75^{\circ}$ longitude.
The vegetation cover for this gridcell in the model is dominated by trees, with a mixture of temperate deciduous and temperate needleleaf evergreen forest, in general agreement with the presence of oak and pine stands in the tracer study. The influence of anthropogenic nitrogen deposition was isolated from the effects of varying $C_{a}$ by differencing the two radiatively uncoupled experiments: $r N-r n$ (Table 1$)$.

\section{Results}

Under the IPCC A2 business-as-usual scenario for fossil fuel emissions we estimate $C_{a}$ of $884 \mathrm{ppm}$ by year $2100 \mathrm{AD}$ in our radiatively-uncoupled experiment (Fig. 2a). Radiative coupling reduces $C_{a}$ by about $6 \mathrm{ppm}$, with a further reduction of about 27 ppm due to anthropogenic $\mathrm{N}$ deposition (Fig. 2b and c). Levels of $C_{a}$ in our results may be underestimated, as our simulations do not yet include carbon flux contributions from historic or predicted future landcover change.

We find that the response of land carbon storage to increasing $C_{a}\left(\beta_{L}\right)$ is approximately three times lower than the mean response from previous coupled models lacking a nitrogen cycle (Fig. 2d). Previous results from the uncoupled land model show that this reduced $\beta_{L}$ is due mainly to the introduction of C-N interaction (Thornton et al., 2007), and results here from the fully-coupled model are in quantitative agreement, in spite of known biases in the coupled climate. The influence of C-N interaction on $\beta_{L}$ reported in Thornton et al. (2007) and shown here for the case of coupling to a GCM has also been recently demonstrated by Sokolov et al. (2008) for land model C-N coupling in a climate model of intermediate complexity.

The land carbon storage response to radiatively forced climate change, characterized as the sensitivity to increasing temperature $\left(\gamma_{L}\right)$, is small and positive throughout the $21 \mathrm{st}$ century in our results, the opposite sign compared to all previous studies using carbon-only models (Fig. 2e), but the same sign and similar magnitude as in Sokolov et al. (2008) for C-N land component in a reduced-complexity climate model. We also find that $\gamma_{L}$ increases modestly over the period 2000-2100 in our results, while it declines over the same period in previous studies (Fig. 2e).

Transient climate sensitivity $(\alpha)$ of our coupled system is in the lower half of the range of previous results from coupled climate-carbon cycle models (Fig. 3a). Climate sensitivity is trending downward through the second half of the 21st century, in agreement with previously published results. Ocean carbon storage response to increasing $C_{a}\left(\beta_{O}\right)$ is lower in our simulation than in any of the previously published studies. The magnitude of $\beta_{O}$ is declining over time, consistent with previous studies (Fig. 3b). The ocean carbon storage sensitivity to increasing temperature $\left(\gamma_{O}\right)$ in our experiments is negative, as found in all previous studies, but its magnitude is at the low end of the previously reported range (Fig. 3c). 

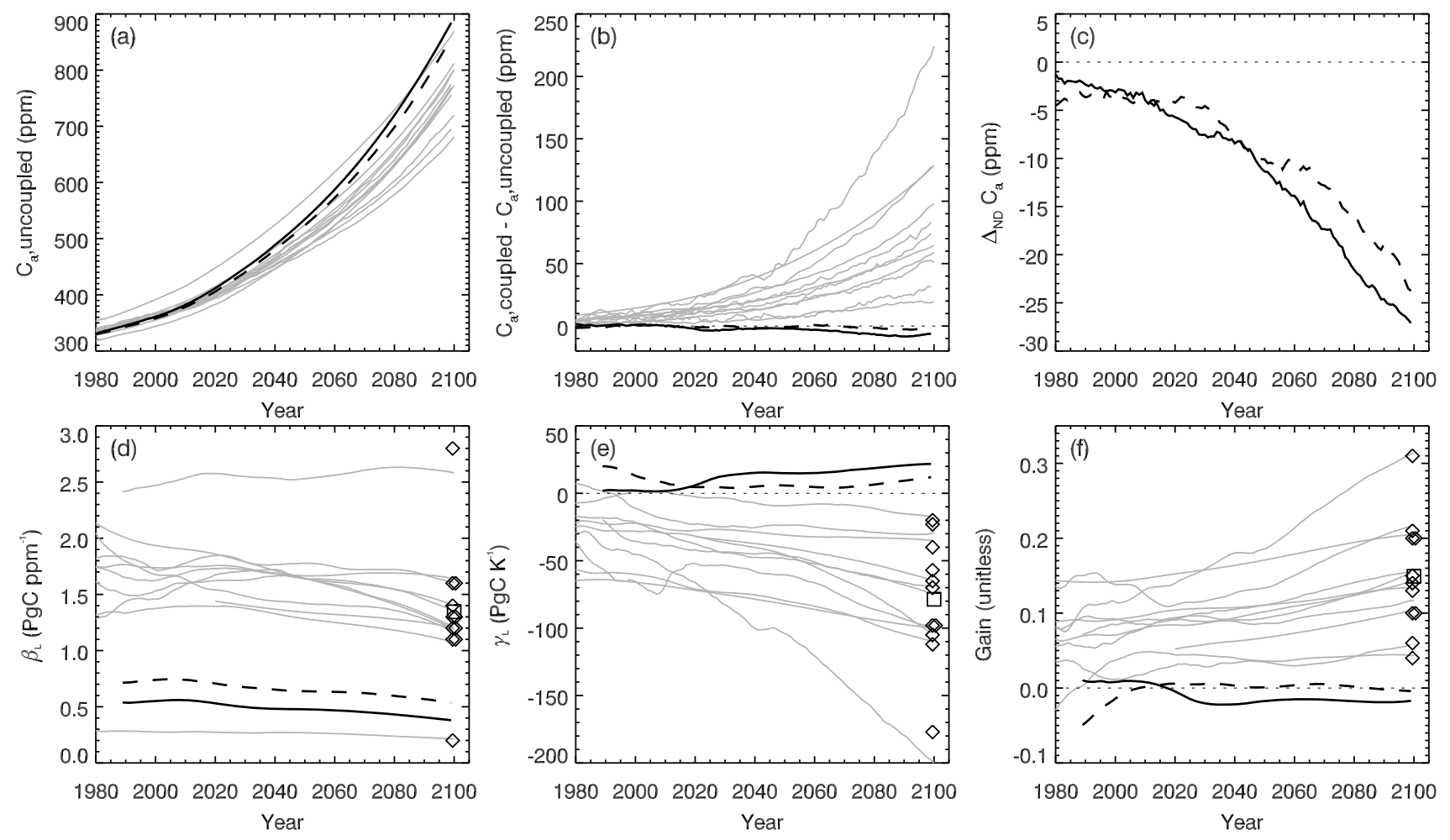

Fig. 2. Predicted atmospheric $\mathrm{CO}_{2}$ and climate-carbon cycle feedback parameters. $C_{a}$ from uncoupled experiments (a); difference in $C_{a}$ due to radiative coupling (b); difference in $C_{a}$ due to anthropogenic nitrogen deposition (c); land biosphere response to increasing $C_{a}$ (d); land biosphere response to increasing temperature (e); and overall global climate-carbon cycle feedback gain (f). Gray lines show archived results from eleven previous studies (Friedlingstein et al., 2006). In all panels except (c), thick solid line is for experiments with preindustrial nitrogen deposition, thick dashed line for anthropogenic nitrogen deposition. In (c), solid and dashed lines are for radiatively uncoupled and coupled experiments, respectively. Diamonds show the feedback parameters estimated at year 2100 for previous studies (Friedlingstein et al., 2006) and square shows their mean. Thin dotted lines indicate zero response.
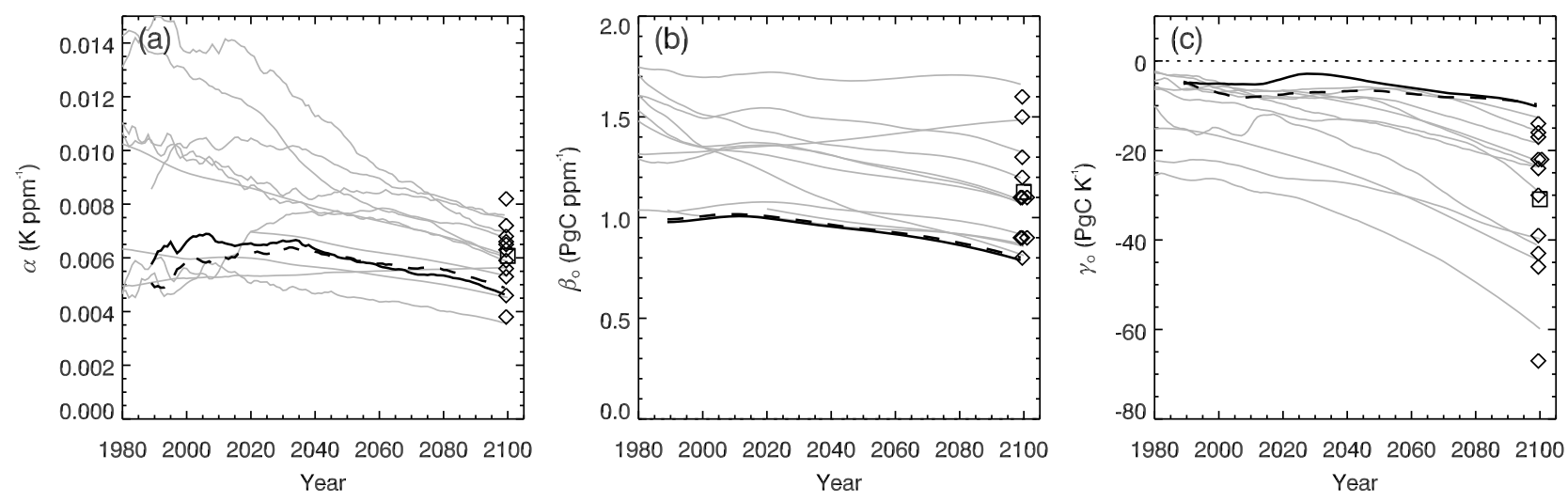

Fig. 3. Atmosphere and ocean feedback parameters. Climate sensitivity to increasing $C_{a}(\alpha)(\mathbf{a})$; ocean carbon cycle sensitivity to $C_{a}\left(\beta_{L}\right)$ (b); and ocean carbon cycle sensitivity to climate $\left(\gamma_{O}\right)$ (c). In all panels thick solid line is for present experiments with preindustrial nitrogen deposition, thick dashed line for anthropogenic nitrogen deposition. Gray lines show the transient responses of eleven previous studies based on archived results, diamonds show the feedback parameters estimated at year 2100 for eleven previous studies as reported in text, and square shows the mean of these previous results. Thin dashed line in (c) indicates zero response. 
Table 2. Influence of temperature and soil moisture on carbon flux components. Multiple linear regression results for $\Delta_{C C}$ of global total carbon flux components $\left(\mathrm{PgC} \mathrm{yr}^{-1}\right)$ predicted by $\Delta_{C C}$ of global mean surface temperature over land $\left(T_{\text {air }}, K\right)$ and global mean plantavailable soil water scalar $\left(B_{\text {tran }}\right.$, converted from proportion (0-1) to $0-100 \%$ ). Net ecosystem exchange of carbon (NEE, normally negative for uptake on land) has been reversed in sign for this analysis, so that the regression coefficients have the same sense as for GPP. All coefficients are significant at the $95 \%$ confidence level. SE: standard error.

\begin{tabular}{lccccccc}
\hline $\begin{array}{l}\text { Carbon flux } \\
\text { component }\end{array}$ & \multicolumn{3}{c}{ Coefficient and (SE) } & \multicolumn{2}{c}{ partial $r^{2}$} & multiple \\
& $\begin{array}{c}\Delta_{C C} T_{\text {air }} \\
\left(\operatorname{PgC~yr}^{-1} \mathrm{~K}^{-1}\right)\end{array}$ & $\begin{array}{c}\Delta_{C C} B_{\text {tran }} \\
\left(\operatorname{PgC~yr}^{-1} \%^{-1}\right)\end{array}$ & $\Delta_{C C} T_{\text {air }}$ & $\Delta_{C C} B_{\text {tran }}$ & $r^{2}$ \\
\cline { 2 - 9 } & 1.26 & $(0.25)$ & 7.06 & $(0.65)$ & 0.21 & 0.55 & 0.56 \\
$\Delta_{C C}$ potential GPP & 5.97 & $(0.19)$ & 4.02 & $(0.50)$ & 0.91 & 0.40 & 0.91 \\
$\Delta_{C C}$ actual GPP & 5.69 & $(0.17)$ & 2.83 & $(0.44)$ & 0.92 & 0.30 & 0.92 \\
$\Delta_{C C}$ ER & 0.08 & $(0.01)$ & -0.19 & $(0.03)$ & 0.28 & 0.25 & 0.50 \\
$\Delta_{C C}$ Fire & 0.20 & $(0.07)$ & 1.38 & $(0.18)$ & 0.08 & 0.38 & 0.38 \\
$-\Delta_{C C}$ NEE & & & & & & & \\
\hline
\end{tabular}

Simulated ocean carbon stock declines by $35 \mathrm{PgC}$ under the influence of radiatively forced climate change over the period 1870-2100. That decline is more than offset by a net increase of $47 \mathrm{PgC}$ on land over the same period, leading to a small negative climate-carbon cycle feedback gain at year 2100, the opposite sign compared to all previous AOGCM studies (Fig. 2f). The $\beta_{L}, \gamma_{L}$, and gain responses all shift toward the carbon-only means under $\Delta_{N D}$ (Fig. 2d-f, dashed lines) as nitrogen limitation is partially relieved by anthropogenic $\mathrm{N}$ deposition, providing initial evidence that $\mathrm{C}-\mathrm{N}$ interaction is an important factor driving the observed differences from previous models. The influence of anthropogenic $\mathrm{N}$ deposition on the feedback parameters mainly conforms to the geographic distribution of the increased deposition (results not shown).

Using a transient feedback analysis, we estimate the influence of C-N coupling on $C_{a}$ in year 2100 by substituting feedback parameter values calculated from the C4MIP archive (Friedlingstein et al. 2006), using multi-model mean parameters as well as single-model parameter substitution from the predecessor C-only CCSM model (CCSM1). Reduced land $\mathrm{CO}_{2}$ fertilization (smaller $\beta_{L}$ ) with the introduction of C-N coupling increases $C_{a}$ by on average $104 \mathrm{ppm}$ (range +65 to $+178 \mathrm{ppm}$ ). Stimulation of carbon uptake under a warming climate (positive $\gamma_{L}$ ) reduces $C_{a}$ on average $82 \mathrm{ppm}$ (range -133 to $-35 \mathrm{ppm}$ ). These two effects of C$\mathrm{N}$ coupling together increase $C_{a}$ on average $16 \mathrm{ppm}$ (range +32 to $-8 \mathrm{ppm}$ ). Anthropogenic nitrogen deposition generates a land sink of $66 \pm 5 \mathrm{PgC}$ over the period 1870-2099, reducing $C_{a}$ by $25 \pm 2 \mathrm{ppm}$ with an associated decrease in the ocean sink of $12 \pm 2 \mathrm{PgC}$. Ranges in the nitrogen depositiondriven sink reflect differences between our radiatively coupled vs. uncoupled experiments.

Spatial and temporal patterns of $\Delta_{C C}$ for temperature and soil moisture are similar to results found previously for CCSM3 (Meehl et al., 2006) (Fig. 4 a-d). CLM-CN calcu- lates gross primary production (GPP) prior to and following nitrogen limitation at each model timestep (potential GPP and actual GPP, respectively). Any differences between $p o-$ tential GPP and actual GPP are directly attributable to the influence of nitrogen limitation in the model, allowing a systematic diagnosis of nitrogen limitation effects on GPP under various forcings. The $\Delta_{C C}$ actual GPP at year 2100 is nearly six times larger than $\Delta_{C C}$ potential GPP $\left(17\right.$ vs. $\left.3 \mathrm{PgC}^{-1}\right)$ (Fig. $4 \mathrm{~g}$ and e). Spatial pattern of $\Delta_{C C}$ potential GPP follows closely the pattern of changes in plant-available soil water $\left(\Delta_{C C} B_{\text {tran }}\right)$ (Fig. 4f and d), consistent with previous results from a carbon-only model (Fung et al., 2005). $\Delta_{C C} a c$ tual GPP is more uniformly positive, with decreases only in small regions with the most extreme decreases in soil moisture (Fig. 4h).

Introduction of nitrogen limitation greatly increases the positive correlation of $\Delta_{C C} G P P$ with $\Delta_{C C} T_{\text {air }}$, and decreases the positive correlation with $\Delta_{C C} B_{\text {tran }}$ (Table 2 and Fig. 5a-d). Climate-driven change in nitrogen mineralization $\left(\Delta_{C C} N_{\min }\right.$, Fig. $4 \mathrm{i}$ and j) is significantly correlated with $\Delta_{C C}$ actual GPP and $\Delta_{C C} T_{\text {air }}$ (Figs. 5i and 6). Increasing $N_{\min }$ is driven by direct nitrogen fertilization for the case of $\Delta_{N D}$ and by climate-driven increase in heterotrophic respiration for the case of $\Delta_{C C}$, but we find that the ratio of increased actual GPP to increased $N_{\min }$ is similar in both cases (Fig. $4 \mathrm{i}$ and $\mathrm{g}$ ).

Total land carbon stock increases by about $50 \mathrm{PgC}$ over the period 2000-2100 under $\Delta_{C C}$ (Fig. 4k). Temperature sensitivities of actual GPP and total ecosystem respiration (ER) nearly cancel, leaving a small net carbon uptake response to increasing temperature, and a moderate response to changing soil moisture (Table 2 and Fig. 5e-h). The strong temperature response of $\Delta_{C C}$ actual GPP results in net uptake in tropical forests of South America, Africa, and Indonesia, even though soil moisture is drier or unchanged in much of the area (Fig. 41 and d). This result is in contrast to previous 
(a)

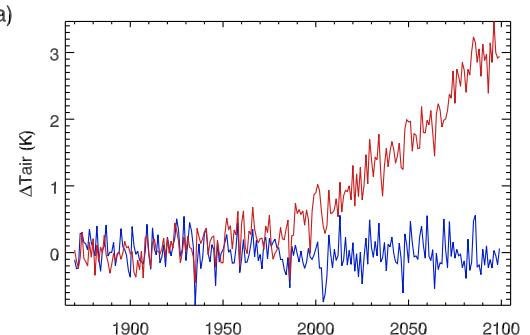

(c)

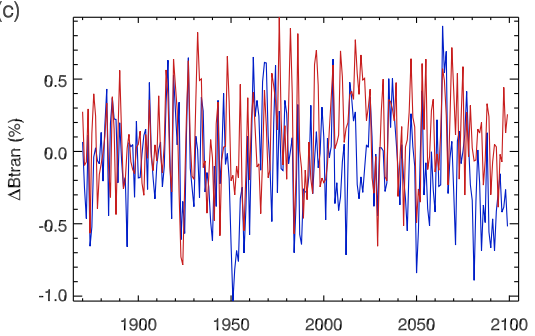

(e)

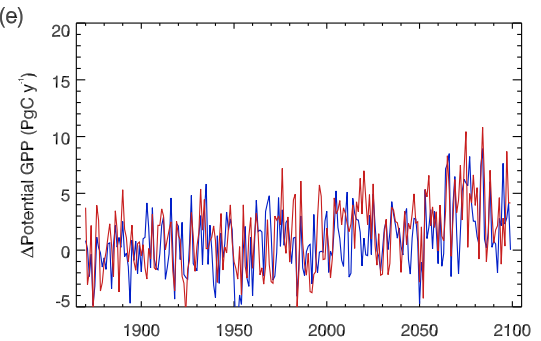

(g)

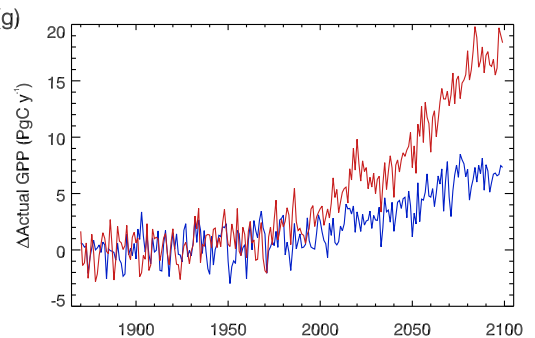

(i)

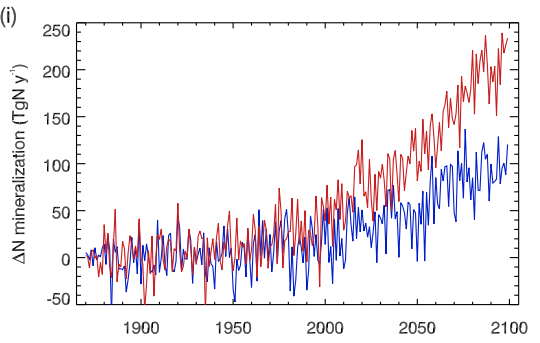

(k)

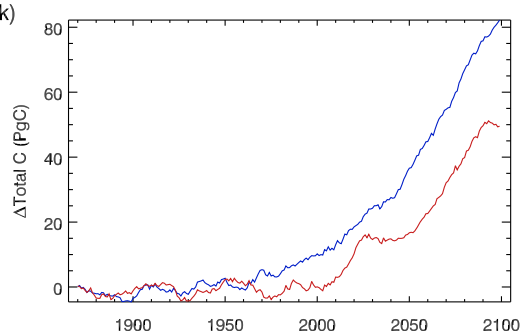

(b)

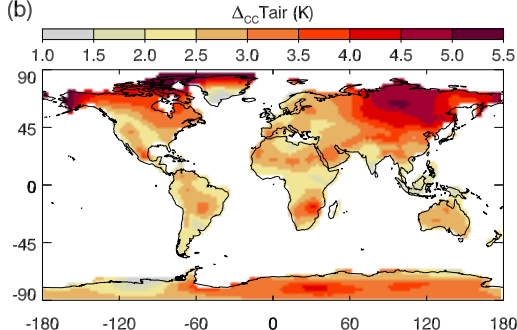

(d)

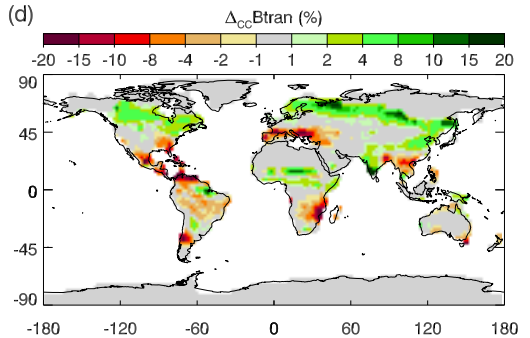

(f) $\quad \Delta_{\mathrm{CC}}$ Potential GPP $\left(\mathrm{kgC} \mathrm{m}^{2} \mathrm{y}^{4}\right)$
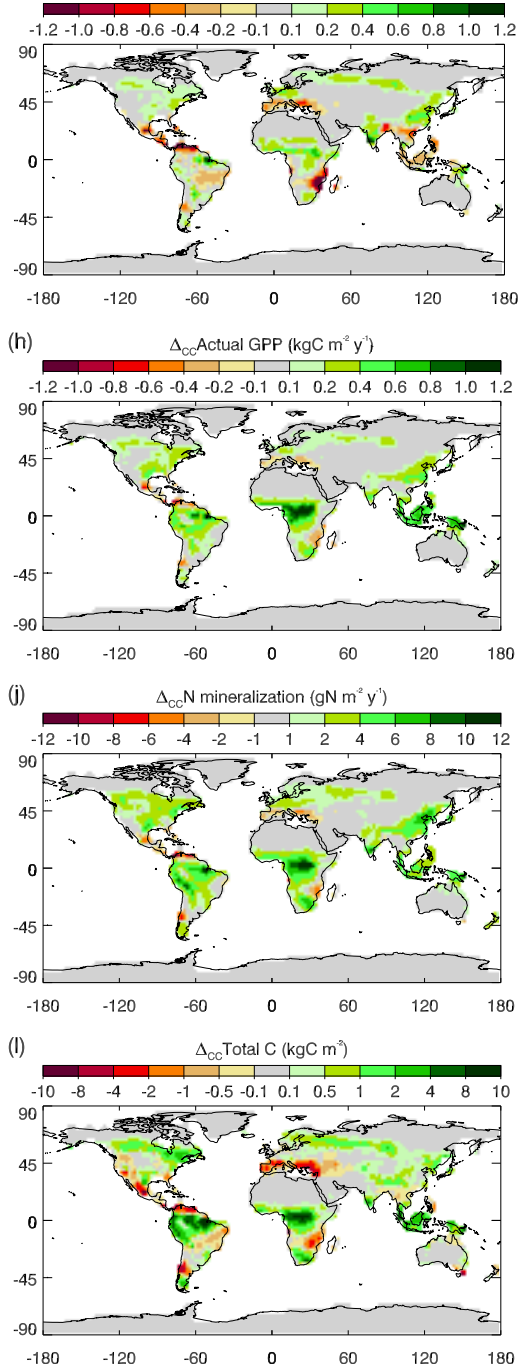

Fig. 4. Effects of radiative coupling and nitrogen deposition. Time series show global means (for $T_{\text {air }}$ and $B_{\text {tran }}$ ) or global totals (for all other quantities) of $\Delta_{C C}$ (red lines) and $\Delta_{N D}$ (blue lines). Maps show $\Delta_{C C}$ averaged over the final decade of simulation (2090-2099). Panels show changes in: $T_{\text {air }}(\mathbf{a}, \mathbf{b}) ; B_{\text {tran }}(\mathbf{c}, \mathbf{d})$; GPP prior to nitrogen limitation (potential GPP) (e, f); GPP following nitrogen limitation (actual GPP) (g, h); gross nitrogen mineralization (i, j); and total land carbon stock $(\mathbf{k}, \mathbf{l})$. 

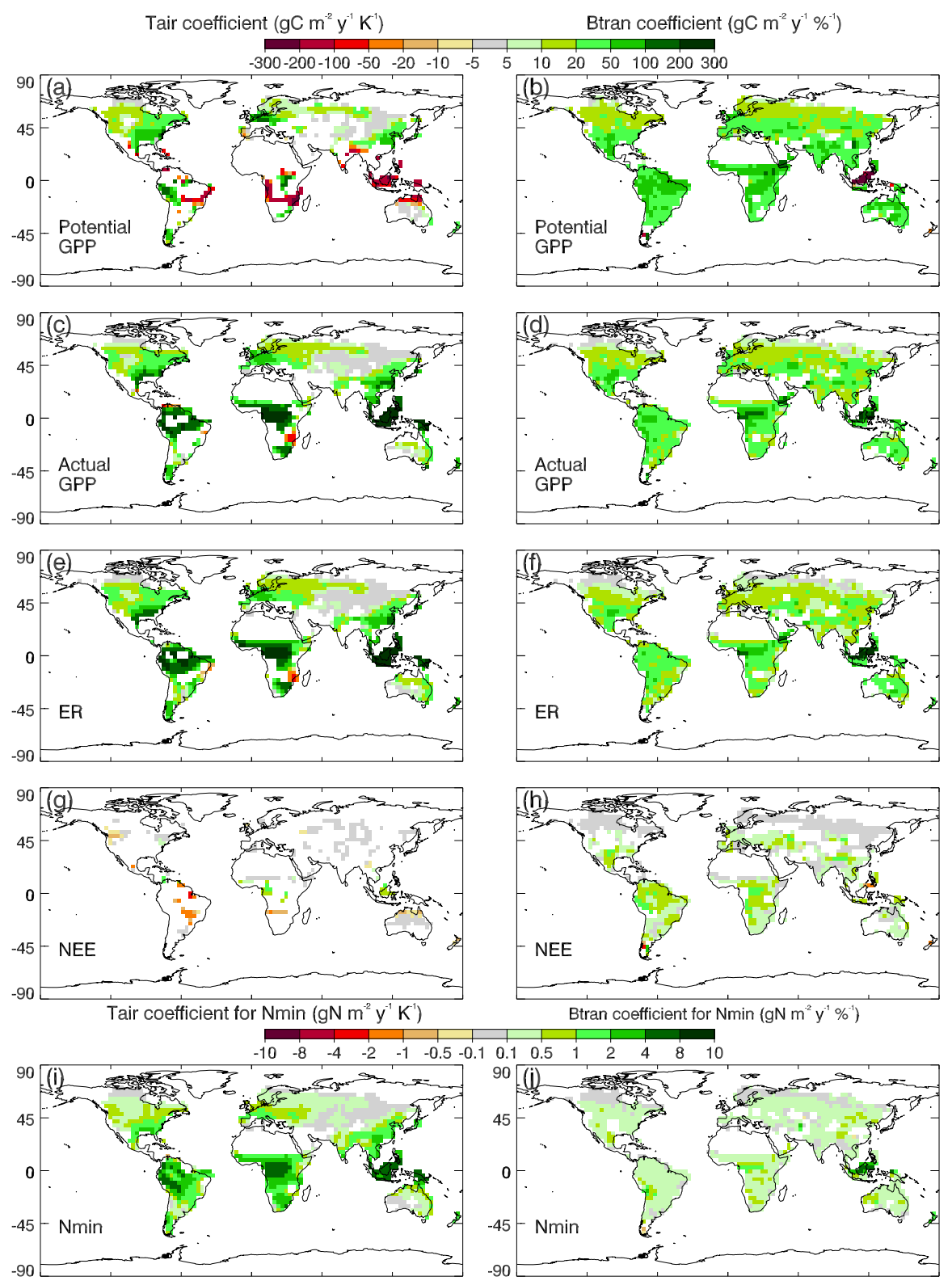

Fig. 5. Multiple regression coefficients for $\Delta_{C C}$ of individual carbon flux components $((\mathrm{a}-\mathrm{h})$, upper color scale) and nitrogen mineralization (i) and (j), lower color scale) predicted by $\Delta_{C C} T_{\text {air }}$ and $\Delta_{C C}$ Btran. Land gridcells with non-significant coefficients (at $95 \%$ confidence level) are white.

carbon-only studies which predicted losses of carbon related to drying soils in these same regions (Fung et al., 2005; Friedlingstein et al., 2006). We find that soil moisture sensitivity causes carbon losses in a few regions with the most extreme drying, including Central America and the Mediterranean region (Fig. $4 \mathrm{l}$ and d).

The increase in total carbon for $\Delta_{C C}$ is caused by an increase in vegetation biomass that is partly offset by declining stocks of litter and soil organic matter (Fig. 7a and b). This result is consistent with the hypothesis that, with warming, nitrogen mineralization from enhanced decomposition im- proves plant nitrogen availability and increases primary production (Stieglitz et al., 2006; McGuire et al., 2000; Arain et al., 2006; Mäkipää et al., 1999; Melillo et al., 2002). We find that $\Delta_{N D}$ increases both soil organic matter and vegetation carbon pools, consistent with recent analyses of carbon uptake under nitrogen fertilization and increasing $C_{a}$ (de Graaff et al., 2006; van Groenigen et al., 2006; Gill et al., 2006).

Nitrogen availability, measured as the ratio (actual GPP:potential GPP), is significantly reduced for $\Delta_{C a}$ (Fig. 7c, green line), consistent with the progressive nitrogen limitation hypothesis (Luo et al., 2004; Reich et al., 

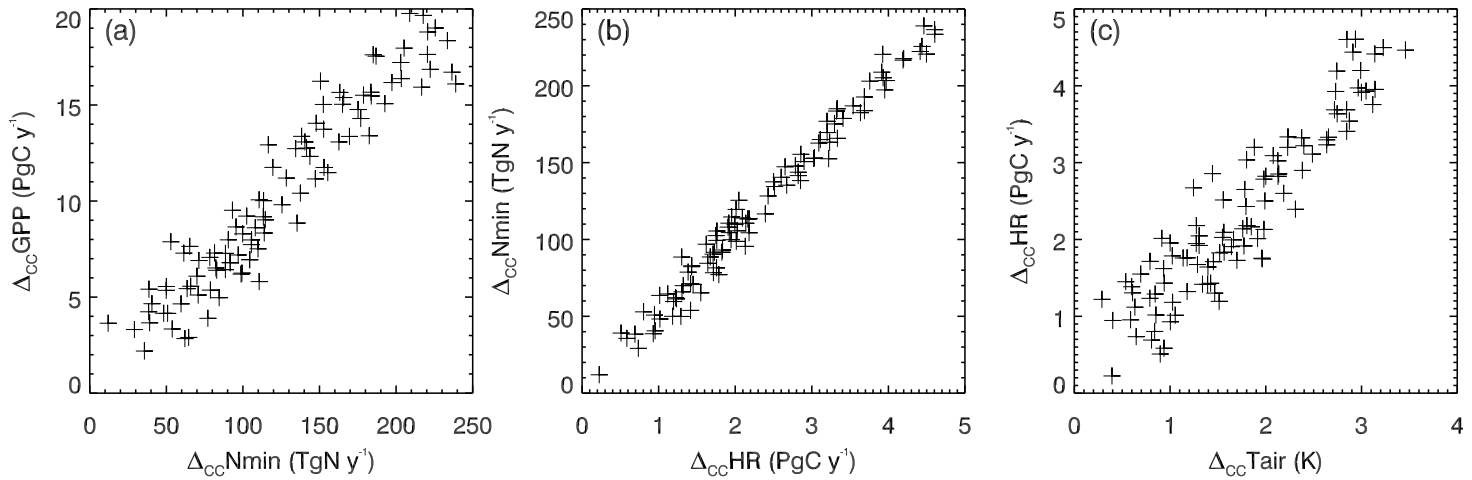

Fig. 6. Scatterplots of $\Delta_{C C}$ GPP vs. $\Delta_{C C}$ Nmin (a), $\Delta_{C C}$ Nmin vs. $\Delta_{C C} \mathrm{HR}$ (b), and $\Delta_{C} \mathrm{HR}$ vs. $\Delta_{C C} T_{\text {air }}$ (c). Plots are based on global total flux or global mean temperature over the period 2000-2099 $(n=100)$.
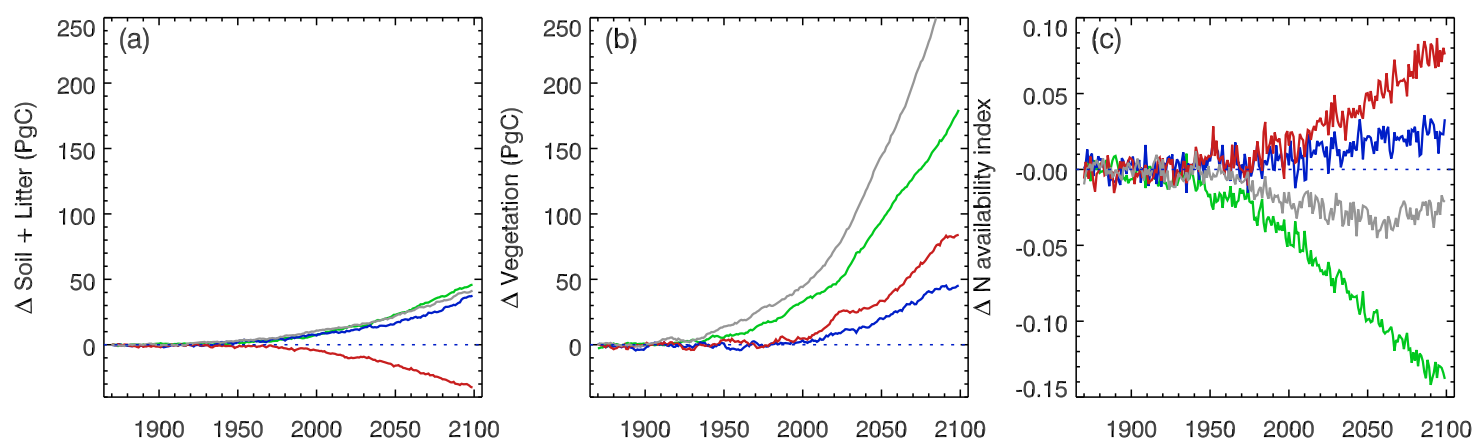

Fig. 7. Changes (due to multiple factors) in global total land carbon stocks for litter and soil organic matter (a), and vegetation (b), and in global mean nitrogen availability index (c). In all panels $\Delta_{C C}$ is shown in red, $\Delta_{N D}$ in blue, $\Delta_{C a}$ in green, and $\left(\Delta_{C C}+\Delta_{N D}+\Delta_{C a}\right)$ in gray.

2006). As expected, $\Delta_{N D}$ results in increased nitrogen availability (Fig. 7c, blue line). The influence of $\Delta_{C C}$ on nitrogen availability has the same sign as $\Delta_{N D}$, and a larger magnitude (Fig. 7c, red line), consistent with our hypothesis that radiatively-forced climate change increases the supply of mineral nitrogen to plants. The progressive nitrogen limitation with $\Delta_{C a}$ in our results is largely mitigated but not completely compensated for by the combination of $\Delta_{N D}$ associated with combustion of fossil fuel (Lamarque et al., $2005)$ and indirect fertilization due to the influence of $\Delta_{C C}$ on nitrogen mineralization (Fig. 7c, gray line).

\subsection{Airborne, land sink, and ocean sink fractions}

Total airborne fraction of anthropogenic $\mathrm{CO}_{2}$ emissions $\left(a_{E}\right)$ over the period 1959-2006 in our experiment $R N$ (radiative coupling and anthropogenic $\mathrm{N}$ deposition) is 0.56 (Table 3 ). Raupach et al. (2008) report $a_{E}=0.43$ for the same period, while Sabine et al. (2004) give a range for $a_{E}$ of 0.41 to 0.53 , with uncertainty arising mainly from assumptions about land use emissions. Our estimates for the land and ocean sink fractions over this period $(0.19$ and 0.25 , respectively, Table 3), are individually within the range of estimates from Sabine et al. (2004) $(0.10$ to 0.41 for the land sink fraction, and 0.18 to 0.36 for the ocean sink fraction), but together they produce an airborne fraction that is outside the range from observations: one or the other, or possibly both, of our sink fraction predictions is too low. Evaluation of the ocean sink against independent observations suggests that the ocean sink strength is too weak, due to weak formation and ventilation of intermediate waters in the Southern Ocean (Appendix A). Evaluation of land ecosystem productivity from a similar version of the model indicates a low productivity bias at high latitudes (Thornton and Zimmermann, 2007), which could lead to a low bias in the land sink strength through an underestimate of the global productivity.

Treatment of land use fluxes could also have an important influence on simulated airborne fraction. Land use fluxes have been intentionally excluded from these simulations. The typical method of dealing with these fluxes in coupled climate-carbon cycle simulations is to specify an assumed flux due to recorded historical and assumed future land use 
Table 3. Airborne fraction, land and ocean sink fractions, and their growth rates. Means and standard deviations over several time periods are shown for the total airborne fraction $\left(a_{E}\right)$, land sink fraction $\left(s_{E, \text { lnd }}\right)$, and ocean sink fraction $\left(s_{E \text {,ocn }}\right)$. Also shown are the proportional growth rates $\left(\% \mathrm{y}^{-1}\right)$ for airborne fraction $\left(r\left(a_{E}\right)\right)$, land sink fraction $\left(r\left(s_{E, \text { lnd }}\right)\right)$, and ocean sink fraction $\left(r\left(s_{E, \text { ocn }}\right)\right)$. Proportional growth rates shown in bold are significant at the $95 \%$ confidence level.

\begin{tabular}{ccccccc}
\hline & \multicolumn{3}{c}{ mean (std. dev) } & \multicolumn{3}{c}{ proportional growth rate, \% y ${ }^{-1}$} \\
\cline { 2 - 7 } Time period & $a_{E}$ & $s_{E, \text { lnd }}$ & $s_{e, \text { ocn }}$ & $r\left(a_{E}\right)$ & $r\left(s_{E, \text { lnd }}\right)$ & $r\left(s_{E, \text { ocn }}\right)$ \\
\hline $1959-2006$ & $0.56(0.10)$ & $0.19(0.11)$ & $0.25(0.03)$ & 0.12 & -0.76 & $\mathbf{0 . 6 4}$ \\
$1959-2099$ & $0.60(0.08)$ & $0.18(0.07)$ & $0.23(0.03)$ & $\mathbf{0 . 1 6}$ & -0.05 & $-\mathbf{0 . 2 3}$ \\
$2000-2099$ & $0.61(0.05)$ & $0.17(0.04)$ & $0.22(0.03)$ & $\mathbf{0 . 2 2}$ & $-\mathbf{0 . 2 4}$ & $\mathbf{- 0 . 4 3}$ \\
$2000-2050$ & $0.58(0.04)$ & $0.18(0.03)$ & $0.24(0.02)$ & 0.10 & 0.22 & $\mathbf{- 0 . 3 7}$ \\
$2050-2099$ & $0.64(0.04)$ & $0.16(0.03)$ & $0.20(0.02)$ & $\mathbf{0 . 3 0}$ & -0.39 & $\mathbf{- 0 . 6 6}$ \\
\hline
\end{tabular}

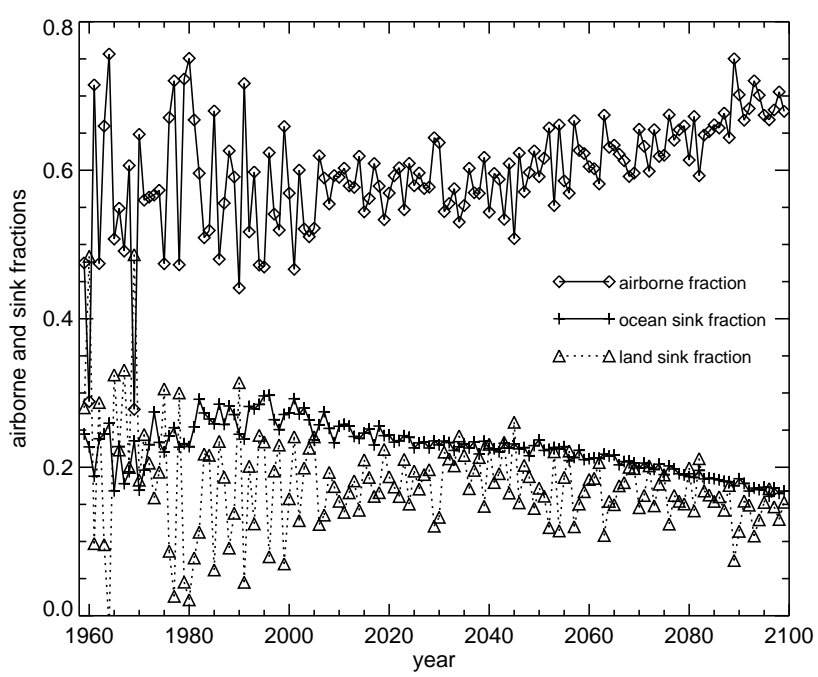

Fig. 8. Simulated airborne fraction, ocean sink fraction, and land sink fraction plotted over the period 1959-2099. Fractions calculated each year as the ratio of the annual increase in the carbon content of the respective pool (atmosphere, ocean, or land) divided by the annual total anthropogenic emissions.

and land cover conversions (McGuire et al., 2001; Friedlingstein et al., 2006). This method does not in any way capture the modeled terrestrial ecosystem response to the disturbances implicit in the land use and land cover change. These responses have been shown, however, to be an important driver of net land carbon fluxes and to have significant interactions with changing $\mathrm{CO}_{2}$ and $\mathrm{N}$ deposition (Thornton et al., 2002). In particular, the standard approach does not capture the influence of prior disturbance on present-day carbon uptake for forests re-establishing on abandoned agricultural land, which is suggested to be an important component of the total land sink in temperate regions (Pacala et al., 2001). Introducing a mechanistic treatment of land cover change could either reduce the predicted land sink fraction through reduction in forest area or increase the land sink fraction by shift- ing forests to younger age-class structures. We are exploring this and other $\mathrm{C}$-N-disturbance interactions as a separate study.

In the absence of anthropogenic nitrogen deposition (experiment $R n) a_{E}$ over the period 1959-2006 is 0.59. Relative to the case with anthropogenic nitrogen deposition, the land fraction drops to 0.14 , with a compensating increase in the ocean fraction to 0.27 . For the period 2050-2099 in the absence of anthropogenic $\mathrm{N}$ deposition the airborne, land, and ocean fractions are $0.67,0.13$, and 0.2 , respectively.

Our model predicts a significant growth in the airborne fraction $\left(r\left(a_{E}\right)\right)$ of $0.22 \% \mathrm{y}^{-1}$ over the period 2000-2099, attributable to declining sink fractions for both land and ocean over this period (Table 3 and Fig. 8). Growth rate for the airborne fraction is lower $\left(0.12 \% \mathrm{y}^{-1}\right)$ over the period 1959 2006, but the result is not significant at the $95 \%$ confidence level. Raupach et al. (2008) estimate $r\left(a_{E}\right)=0.24 \% \mathrm{y}^{-1}$ over the period 1959-2006. Variability in $a_{E}$ is driven mainly by variability in the land sink fraction $\left(s_{E, \text { lnd }}\right)$ in our results (Fig. 8), with variability decreasing over time. Our results suggest a significant increase in the airborne fraction growth rate in the latter half of the 21 st century. This appears to be the result of a steadily declining ocean sink fraction over the 21 st century and a declining land sink fraction over the period 2050-2099 (Fig. 8), although the decline in land sink fraction is not significant at the $95 \%$ confidence level (Table 3).

\subsection{Fate of additional $\mathbf{N}$}

Our results for the region around the Harvard Forest study site show a 30-40 year lag between the onset of anthropogenic $\mathrm{N}$ deposition (new mineral $\mathrm{N}$ input) and increased losses due to denitrification (Fig. 9a and b). Cumulative denitrification losses grow rapidly to $50 \%$ of cumulative new inputs after $40-50$ years, and eventually stabilize close to $75 \%$ of cumulative new inputs (Fig. 9b).

During the first 40 years of the simulation, when losses of new inputs due to denitrification are low, most of the 
(a)

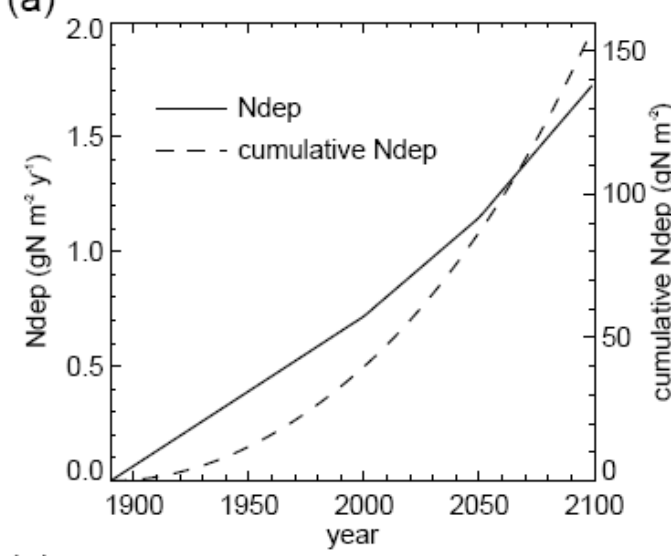

(c)

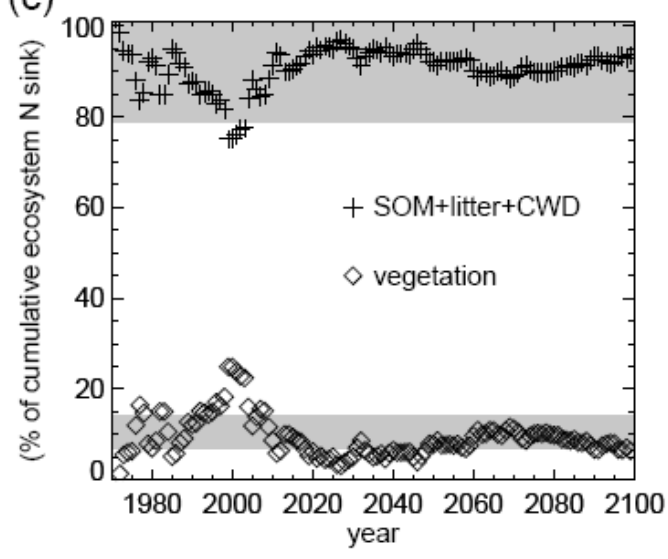

(b)

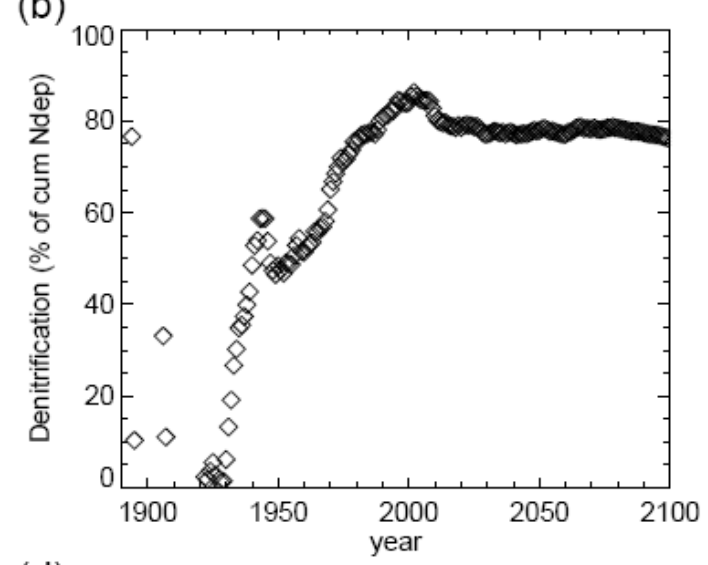

(d)

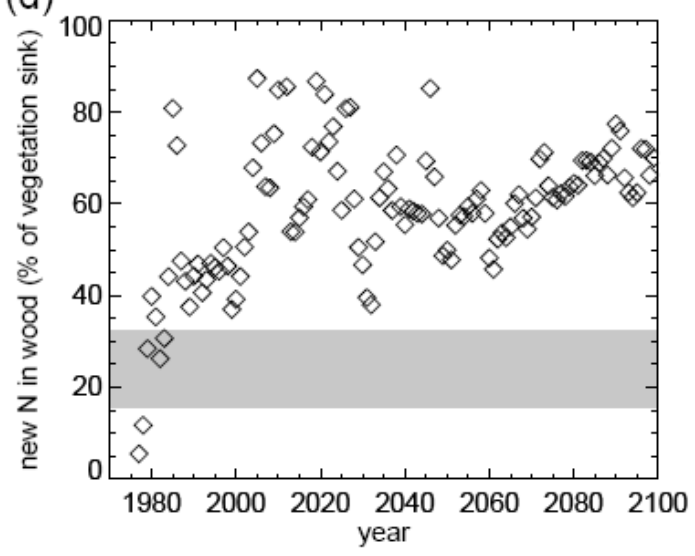

Fig. 9. Comparison of modeled and observed fate of new mineral $\mathrm{N}$ introduced by anthropogenic $\mathrm{N}$ deposition near Harvard Forest. Annual mineral anthropogenic $\mathrm{N}$ deposition and cumulative anthropogenic $\mathrm{N}$ deposition over the period 1890-2099 (a). Cumulative denitrification as a \% of cumulative anthropogenic $\mathrm{N}$ deposition (Ndep) (b). Anthropogenic nitrogen deposition stored in soil organic matter (SOM)+litter+coarse woody debris (CWD) and stored in vegetation, shown as \% of cumulative ecosystem N sink (c). Anthropogenic nitrogen deposition stored in wood, as a \% of total vegetation sink for new nitrogen (d). Observed ranges shown as gray bars in cC and $\mathrm{d}$ (see text).

additional $\mathrm{N}$ is accumulating in soil (results not shown). The differencing of two independent coupled climate simulations required to extract the $\mathrm{N}$ deposition signal makes it difficult to quantify the fraction of new input $\mathrm{N}$ that accumulates in vegetation during the early years of the simulation - the signal is overwhelmed by variability due to independent climate realizations. After about 90 years the anthropogenic $\mathrm{N}$ deposition signal is strong enough to begin to resolve the accumulation in vegetation vs. litter and soil pools, and also to resolve the fractions accumulating in woody vs. non-woody vegetation pools. Over the period 1980-2100 the fraction of increased $\mathrm{N}$ stocks accumulating in vegetation varies in the range $4-25 \%$, with generally higher values early in that period and lower values later (Fig. 9c). The large majority of new $\mathrm{N}$ stocks are still accumulating in soil organic matter during this period. Of the new $\mathrm{N}$ accumulating in vegetation, the contribution of woody biomass increases over time from $40 \%$ for the period $1980-1999$ to $70 \%$ for the period 2080-2099 (Fig. 9d).

These results are broadly consistent with the observed partitioning of accumulated ${ }^{15} \mathrm{~N}$ tracer at Harvard Forest, where Nadelhoffer et al. (2004) (hereafter Nad04) found a range of $6.8-14.3 \%$ of tracer $\mathrm{N}$ in vegetation 7 years after application in their control plots, with $78.8-100.4 \%$ of tracer $\mathrm{N}$ in organic and mineral soil (ranges shown as shaded regions in Fig. 9c). The fraction of vegetation tracer $\mathrm{N}$ residing in wood was lower for Nad04 than in our simulations (15.7$32.3 \%$, shaded region in Fig. 9d), but was increasing with time in their control plots. We are not able to resolve the vegetation signal for the first 90 years of the simulation, but the trend in model results shown in Fig. 9d suggests that the model has a lower fraction of new $\mathrm{N}$ in wood earlier in the simulation. This behavior is consistent with the hypothesis put forward in Nad04 that tracer $\mathrm{N}$ is accumulating in woody 
tissue over time, at least in their control plots where the rates of background nitrogen deposition (reported in Nad04 as $0.8 \mathrm{gN} \mathrm{m}^{-2} \mathrm{y}^{-1}$ ) are in excellent agreement with our modeled $\mathrm{N}$ deposition rates at present day for this region (Fig. 9a).

\section{Discussion}

\subsection{Influence of $\mathrm{C}-\mathrm{N}$ coupling on $\mathrm{C}_{a}$}

We predict that introduction of $\mathrm{C}-\mathrm{N}$ interactions in the land component of a coupled climate-carbon cycle AOGCM causes a reduction in terrestrial carbon sink strength under increasing $C_{a}$, which is only partly offset by the N-mediated reversal of the land response to radiatively-forced climate change from a net source to a net sink. The overall effect of C-N interaction in the current model results is to reduce the fraction of anthropogenic emissions stored in land ecosystems, compared to models lacking $\mathrm{C}-\mathrm{N}$ interactions. Since our simulation did not include any influence of changing landcover, it is likely that the present model configuration would result in a significantly higher $C_{a}$ by the end of the 21 st century under a business-as-usual scenario for fossil fuel and land use emissions, compared to previous coupled climate-carbon cycle modeling results.

Significant interactions among increasing $C_{a}$, anthropogenic $\mathrm{N}$ deposition, and disturbance history have been documented through site-level measurements and modelmeasurement comparisons (Ollinger et al., 2002; Thornton et al., 2002; Goodale and Aber, 2001), and we expect that C-N interactions will strongly influence global-scale predictions of net greenhouse gas emissions due to changing land use and land cover. Previous coupled climate system model results found a reasonable match to present-day $C_{a}$ for some models with much larger $\beta_{L}$ than predicted here (Friedlingstein et al., 2006). Strong land uptake due to $\mathrm{CO}_{2}$-fertilization in those models is partly balanced by carbon emissions from landuse change. These earlier simulations used a simple prescribed deforestation carbon source term, and did not include the dynamics of land use change and the potential for evolving sources and sinks related to land use history. In particular, we expect that mid-latitude carbon sinks due to reforestation on abandoned agricultural land may help to offset the low $\mathrm{CO}_{2}$ fertilization effect in our $\mathrm{C}-\mathrm{N}$ coupled land model (Pacala et al., 2001; Hurtt et al., 2006; Stephens et al., 2007). We are currently exploring these interactions.

The magnitude and sign of the overall climate-carbon feedback (gain) predicted here depends on the magnitude and sign of the feedback components as given in Eq. (4). A low value of the transient climate sensitivity to greenhouse gas forcing $(\alpha)$ compared to previous studies tends to reduce the magnitude of gain, regardless of its sign. If $\alpha$ is found to have a low bias in this model, the overall negative climate-carbon cycle feedback may have a larger magnitude than predicted here, which would lead to reduction in $C_{a}$. However, the negative sign of gain is due to the fact that the small positive value for $\gamma_{L}$ is able to cancel the small negative value for $\gamma_{O}$. We note that $\gamma_{O}$ here $\left(-10 \mathrm{PgC} \mathrm{K}^{-1}\right)$ is smaller in magnitude than any of the C4MIP models (Fig. 3c) (range: -16 to $-67 \mathrm{PgC} \mathrm{K}^{-1}$ ). If the magnitude of $\gamma_{O}$ is too low, the modest positive value for $\gamma_{L}$ suggests that the true gain may be positive, which would result in higher values for $C_{a}$. If $\beta_{O}$ is biased low, as suggested by comparison to other models (Fig. 3b) and comparison against ocean tracers (Appendix A), then the magnitude of gain may be overstated, whatever its sign.

While our current model does include gaseous nitrogen losses from soil as an important process regulating the longterm accumulation of nitrogen stocks, we are not presently accounting for the greenhouse forcing consequences of $\mathrm{N}_{2} \mathrm{O}$ emissions. We expect these emissions to scale approximately with total decomposition, and so in general to increase under a warmer climate with more active heterotrophic respiration.

\subsection{Representation of nutrient limitations in the tropics}

An important source of uncertainty for the results presented here has to do with the nature and extent of limitation from nutrients other than nitrogen, and particularly the role of phosphorus limitation in tropical forests. The meta-analysis by LeBauer and Treseder (2008) of nitrogen addition experiments shows that $\mathrm{N}$ limitation is observed in both upland and lowland tropical forests. In conjunction with additional meta-analysis of combined $\mathrm{N}$ and $\mathrm{P}$ experiments (Elser et al., 2007) it appears that lowland primary tropical forest is likely more limited by $\mathrm{P}$ than by $\mathrm{N}$ availability, while lowland secondary and upland forest may exhibit the same degree of $\mathrm{N}$ limitation as observed in temperate forest.

A critical issue is whether the prediction of C-climate feedbacks in the lowland primary tropical forest ecosystem is approximated better by the introduction of $\mathrm{C}-\mathrm{N}$ interactions, or by leaving out the $\mathrm{C}$-nutrient interactions altogether. In Thornton et al. (2007) we set forward the hypothesis that inclusion of C-N dynamics might be a reasonable first-order approximation for both $\mathrm{N}$ and $\mathrm{P}$ limitations. Since the shortterm (years to decades) availability of both $\mathrm{N}$ and $\mathrm{P}$ incorporated into annual plant growth is dictated mainly by the rate of decomposition of soil organic matter and the associated mineralization of previously organically bound nutrients, we suggest that $\mathrm{N}$ limitation serves as a useful lower-bounding nutrient limitation proxy for the case of ecosystems where the $\mathrm{P}$ limitation is dominant, or with N-P colimitation.

An important counter-argument to this N-proxy hypothesis is that the coupling of $\mathrm{N}$ and $\mathrm{P}$ dynamics is complicated by the connection between P-availability and biological $\mathrm{N}$ fixation (Wang et al., 2007; Houlton et al., 2008), which could lead to a coupled N-P limitation that is smaller than the simple N-proxy limitation. In that case the results presented here could be overstating the importance of the real C-nutrient interaction effect on the C-climate feedback components. We 
have tried to mitigate against the possibility of severe biases in this direction by incorporating a prognostic calculation of biological N fixation (BNF) into CLM-CN. This formulation captures the first-order dependencies of BNF on climate and carbon availability by making BNF a saturating function of net primary production (Thornton et al., 2007).

\subsection{Influence of $\mathrm{C}-\mathrm{N}$ interactions on model uncertainty}

In spite of the potential biases discussed above, we expect that the uncertainty in previous estimates of $\beta_{L}, \gamma_{L}$, and gain (Friedlingstein et al., 2006) (Fig. 2d-f) would be significantly reduced if explicit $\mathrm{C}-\mathrm{N}$ interactions were introduced in other models. This expectation is based on the following consideration of the sign of the effect of $\mathrm{C}-\mathrm{N}$ interactions on the feedback components and the logical bounds on those parameters.

We consider any reasonable estimate of $\beta_{L}$ to be bounded below by zero, since there is no evidence suggesting that increasing $C_{a}$ could lead to a global-scale reduction in land carbon storage. We posit that introduction of any new constraint on vegetation growth response, such as an explicit dependence on nitrogen availability to support new growth, can only produce a reduction in the estimated response of land carbon uptake to $\mathrm{CO}_{2}$ fertilization. So introduction of C-N coupling in a model that previously considered only the carbon cycle will lead to a reduced $\beta_{L}$. The range of estimates for $\beta_{L}$ shown in Fig. $2 \mathrm{~d}$ will therefore be compressed as more models introduce an explicit treatment of nitrogen limitation, leading to a smaller range in predicted land carbon uptake under a common emissions scenario.

There is not an obvious logical bound on the sign of the land carbon storage response to radiatively-forced climate change, as evidenced by the spatial variability in the sign of the response demonstrated for both carbon-only (Fung et al., 2005) and carbon-nitrogen model results (Fig. 4l). We do expect, however, that a general response to introduction of $\mathrm{C}-\mathrm{N}$ coupling will be an increased dependence of primary production on heterotrophic respiration. This should damp the tendency, demonstrated by all the previous carbon-only models, to release carbon from land under a warmer climate. $\mathrm{C}-\mathrm{N}$ coupling should therefore shift the range of model results shown in Fig. 2e in the direction of our C-N coupled result. We also hypothesize that because this response depends on a strong coupling between production (carbon uptake) and respiration (carbon release), there is an upper limit to the response at some moderate positive value for $\gamma_{L}$. Introduction of C-N coupling is therefore expected to compress the between-model range of $\gamma_{L}$. Results from a coupled model of intermediate complexity support this hypothesis (Sokolov et al., 2008). A comparison of dynamic global vegetation models suggests that inclusion of dynamic biogeography might complicate the influence of $\mathrm{C}-\mathrm{N}$ coupling on the land ecosystem response to warming (Cramer et al., 2001). In addition to the warming-related mechanism of C-
$\mathrm{N}$ interaction, other mechanisms related to changing nitrogen status are likely to play an important role, such as changes in species composition and associated changes in ecosystem structure and function (Suding et al., 2005) and changes in allocation patterns (Norby and Iversen, 2006).

Long-term multi-site flux observations (Law et al., 2002), ecosystem manipulation experiments (Norby and Iversen, 2006; Finzi et al., 2007; Melillo et al., 2002), and land carbon fluxes from data-assimilation methods (Peters et al., 2005) provide strong observational constraints that will be critical to the evaluation of the predicted climate-carbon-nitrogen dynamics reported here. Recent work with the CCSM suite of models clearly demonstrates the usefulness of model evaluation against multiple observational constraints (Randerson et al., 2009) as a way to improve model parameterization and performance, and several additional efforts are currently underway.

\subsection{Fate of input $N$}

In our simulations, the influence of C-N coupling on the climate-carbon feedback depends on the fate of newly mineralized $\mathrm{N}$, in particular whether it accumulates mainly in soil organic matter or in woody tissue. Confidence in this result demands that the same model be able to predict the fate of new $\mathrm{N}$ introduced directly through fertilization. We are fortunate to have as a point of reference in this regard the results of ${ }^{15} \mathrm{~N}$ tracer experiments as reported by Nadelhoffer et al. (2004) (Nad04), but a completely consistent comparison of our results with the Harvard Forest tracer experiments is not possible, due to the other requirements of our experimental protocol and limited computational resources. We find, however, that a broad comparison of our results with those of Nad04 shows an encouraging degree of qualitative as well as quantitative correspondence.

Our result showing a nearly complete retention of new input $\mathrm{N}$ for the first several decades of low-level $\mathrm{N}$ addition is consistent with the near-complete recovery of tracer $\mathrm{N}$ in the Nad04 control plots after 7 years. Our results suggest that a longer manipulation would be required to see significant gaseous losses on the control plots, but those results may be sensitive to the level of $\mathrm{N}$ fertilization. Even at year 2099 the anthropogenic $\mathrm{N}$ deposition in our simulations for the Harvard Forest grid point are well below even the low-N fertilization plots in Nad04. Additional modeling experiments are required to evaluate the influence of higher $\mathrm{N}$ input rates on this predicted time lag.

We also find that the dominant ecosystem sink for new $\mathrm{N}$ inputs is into soil organic matter, consistent with Nad04. This is true during periods of both low and high denitrification losses. When the signal:noise of our differenced coupled simulations is high enough to resolve the fraction of the ecosystem sink accumulating in vegetation (after 1980), we find a good quantitative agreement with $\mathrm{Nad04}$, with our predicted fractions of the $\mathrm{N}$ sink into vegetation and litter/soil 
organic matter falling within the observed range for most of the period 1980-2099. Fractions of deposited N recovered in vegetation, litter, and soils vary across multiple studies, but in general the total fraction recovered in litter and soil is larger than the fraction recovered in vegetation (Schlesinger, 2009).

We stress that there are some issues with our experimental protocol that leave an imperfect basis for comparison. The values shown for the model in Figure 8 are percentages of the cumulative ecosystem sink, and are significantly smaller and outside the observed range if expressed on the basis of cumulative anthropogenic $\mathrm{N}$ deposition inputs. Our results suggest that the modeled denitrification flux associated with the new input $\mathrm{N}$ would be very small for the 7-year observation period reported in $\mathrm{Nad} 04$ if the modeled $\mathrm{N}$ addition were a short pulse over 1991-1992 as in the field experiment. We also note that the qualitative agreement in terms of the large fraction of the modeled $\mathrm{N}$ sink going to litter and soil organic matter holds well both before and after the transition to denitrification losses. Ignoring the denitrification component therefore provides the most logical basis for comparison, but we recognize that additional evaluation work should be done to test our model more exactly against the experimental conditions of Nad04.

\section{Conclusions}

Results reported here support the conclusion that tight coupling of carbon and nitrogen cycles in the terrestrial biosphere has the following important consequences for climate system - carbon cycle feedbacks and resulting changes in $C_{a}$ :

1. Terrestrial C-N interaction greatly reduces the capacity of land ecosystems to increase net carbon uptake in response to increasing atmospheric $\mathrm{CO}_{2}$ concentration, compared to the same response when nutrient limitations are ignored. This conclusion is supported by previous studies: for stand-alone ecosystem models (McGuire et al., 2001), offline land component of a coupled climate model (Thornton et al., 2007), coupled model of intermediate complexity (Sokolov et al., 2008), and now here for the case of a fully-coupled climate system model. We note that each of these studies is based on either the TEM or the CLM-CN model.

2. Terrestrial C-N interaction leads to an increase in $\gamma_{L}$, the sensitivity of land carbon uptake to radiativelyforced climate change, moving the overall climatecarbon cycle feedback in the direction of a smaller positive feedback than previously assumed (Friedlingstein et al., 2006; Denman et al., 2007), including the possibility of a modest negative feedback. The mechanism controlling this response is the interdependence of primary production and heterotrophic respiration, mediated by the cycling of mineral and organic forms of nitrogen in the plant-litter-soil system.

3. Decreased $\mathrm{CO}_{2}$ fertilization effect and smaller carbon losses (or even carbon gain) under radiatively forced climate change have opposing influence on $C_{a}$, but our results suggest that the net effect of introducing C-N dynamics is to increase the airborne fraction of anthropogenic emissions, and so increase the simulated $C_{a}$ for a given emissions scenario.

These conclusions are supported by the following lines of evidence, establishing causality in the simulation results and evaluating these results against experimental studies:

- Introduction of anthropogenic nitrogen deposition shifts the predicted climate-carbon cycle feedback parameters toward the mean response of previously-reported carbon-only models.

- Introduction of C-N interaction greatly increases the sensitivity of primary production to radiatively-forced climate warming, and this increase is directly associated with a warming-induced increase in nitrogen mineralization. This factor increases the importance of temperature change and reduces the relative importance of soil moisture change on the spatial pattern of land carbon cycle response to climate change.

- Climate warming drives a transfer of nitrogen out of soil organic matter and into vegetation, influenced by a demand-based competition between plants and microbes for the available mineral nitrogen resource.

- The simulated fate of new mineral nitrogen, with respect to ecosystem losses and accumulation in vegetation and soil pools, is in good qualitative and quantitative agreement with ${ }^{15} \mathrm{~N}$ tracer experiments in a temperate forest ecosystem. The relative accumulation of new nitrogen in woody vs. non-woody vegetation tissue is less conclusive, but results suggest a good qualitative agreement.

We argue that between-model variation in land carbon cycle responses to both $\mathrm{CO}_{2}$ fertilization and climate change would be reduced by the introduction of $\mathrm{C}-\mathrm{N}$ interactions in other climate-carbon cycle models, which would tend to reduce the range of uncertainty in predictions of future climate from the coupled models. Finally, we note that the present simulations have not included the influence of disturbance history and land use. These factors have been shown to interact strongly with $\mathrm{C}-\mathrm{N}$ dynamics. We are currently exploring these interactions in the context of the fully-coupled climate system model, and we expect that these interactions will result in larger values of atmospheric $\mathrm{CO}_{2}$ concentration than predicted here. 

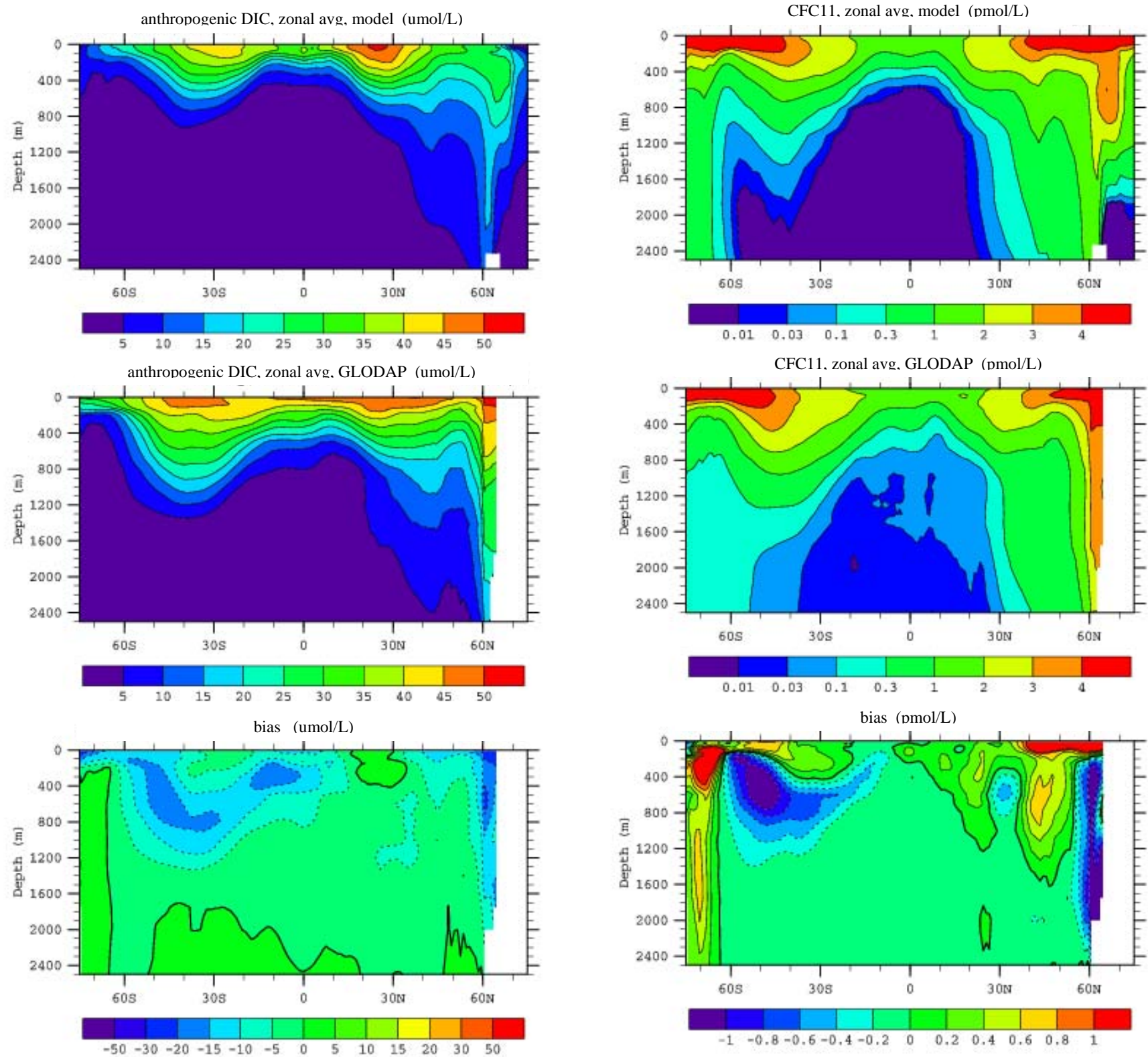

Fig. A1. Zonal average of anthropogenic dissolved inorganic carbon (DIC). See text for discussion of averaging time periods. Model (top), GLODAP measurements (middle), and model bias (bottom).

\section{Appendix A}

\section{Ocean $\mathrm{CO}_{2}$ and $\mathrm{CFC}$ analysis}

The sensitivity of ocean carbon uptake to changes in atmospheric $\mathrm{CO}_{2}$ in the CCSM 3.1-carbon simulations (reported here) is at the low end of published values. Values of the ocean carbon sensitivity, $\beta_{O}$, are equal to about $1.0 \mathrm{PgC} \mathrm{ppm}{ }^{-1}$ over the first half of the 21 st century, declining to $0.8 \mathrm{PgC} \mathrm{ppm}^{-1}$. By comparison, the range of

Fig. A2. Zonal average of CFC-11. See text for discussion of averaging time periods. Model (top), GLODAP measurements (middle), and model bias (bottom).

$\beta_{O}$ reported for the C4MIP models is 0.8 to $1.6 \mathrm{PgC} \mathrm{ppm}^{-1}$ (Friedlingstein et al., 2006). To assess whether this low ocean carbon sensitivity is reasonable, we compare the CCSM 3.1-carbon results against observed ocean tracer distributions for the contemporary period (Matsumoto et al., 2004). We use globally gridded fields from the GLODAP project derived from the World Ocean Circulation Experiment (WOCE) in the 1990s (Key et al., 2004). We focus on two tracers: empirically derived anthropogenic carbon estimates (Sabine et al., 2004) and chlorofluorocarbon CFC-11, an inert tracer produced solely by industrial processes (Dutay 
et al., 2002). The simulated CFC data are extracted for 1994, to match the mid-point of the WOCE CFC data. The model analysis period is shifted slightly for anthropogenic carbon to 1994-2008 so that the model atmospheric $\mathrm{CO}_{2}$ levels match that for the WOCE period.

The simulated zonal average anthropogenic carbon distribution in our results exhibits similar depth and latitudinal patterns as the observed fields (Fig. A1). But the model tends to underestimate anthropogenic carbon, relative to the field derived estimates, in the Southern Hemisphere, along ventilation pathways of Antarctic intermediate and mode waters, and in the northern North Atlantic. Globally the simulated anthropogenic $\mathrm{CO}_{2}$ inventory for the WOCE period is $42 \%$ lower than observed estimates, which are presented with a $16 \%$ uncertainty. The observational derived anthropogenic carbon is a derived rather than directly measured quantity and thus has its own potential biases and uncertainties. In contrast, there are no natural sources for CFC-11, and while not a perfect analogue for anthropogenic $\mathrm{CO}_{2}$ because of differences in gas exchange and the temperature sensitivity of solubility, the growth rates of atmospheric CFC- 11 and $\mathrm{CO}_{2}$ matched well for much of the latter half of the 20th century.

The error patterns in the simulated zonal average distribution of chlorofluorocarbon CFC-11 (Fig. A2) are similar to those of anthropogenic carbon. In particular, the CFC modeldata biases suggest that the model has too strong ventilation right near Antarctica with diminished ventilation of Antarctic intermediate and mode waters. And in the northern North Atlantic, the CFCs show how model convection is shifted too far south. Positive CFC-11 biases are found in subpolar and polar surface waters, associated with model temperature biases. Excluding the Arctic Ocean, which is poorly sampled, the simulated CFC inventory for the WOCE period is $11 \%$ lower than observed estimates, which are presented with a $15 \%$ uncertainty. The CFCs appear to confirm that the low ocean carbon sensitivity $\beta_{O}$ for the present results and the underestimated anthropogenic carbon uptake over the historical period reflect, at least in part, an overly weak formation and ventilation of intermediate waters in the Southern Ocean.

Acknowledgements. We thank G. Bonan, D. Schimel, and E. Holland for helpful discussions throughout this effort. We also thank V. Arora, C. Jones, and two anonymous reviewers for their constructive comments on the manuscript. This work was supported in part by NASA Earth Science Enterprise, Terrestrial Ecology Program, grant \#W19,953 to P. E. Thornton. Support was provided by the National Center for Atmospheric Research (NCAR) through the NCAR Community Climate System Modeling program, and through the NCAR Biogeosciences program. Additional support was provided by the US Department of Energy, Office of Science, Office of Biological and Environmental Research. I. Fung, S. Doney, N. Mahowald, and J. Randerson acknowledge support from National Science Foundation, Atmospheric Sciences Division, through the Carbon and Water Initiative. NCAR is sponsored by the National Science Foundation.

Edited by: L. Bopp

\section{References}

Andres, R. J., Marland, G., Fung, I., and Matthews, E.: A one degree by one degree distribution of carbon dioxide emissions from fossil fuel consumption and cement manufacture, 1950-1990, Global Biogeochem. Cy., 10, 419-429, 1996.

Arain, M. A., Yuan, F., and Black, T. A.: Soil-plant nitrogen cycling modulated carbon exchanges in a western temperate conifer forest in Canada, Agr. Forest Meteorol., 140, 171-192, 2006.

Collins, W. D., Bitz, C. M., Blackmon, M. L., Bonan, G. B., Bretherton, C. S., Carton, J. A., Chang, P., Doney, S. C., Henderson, T. B., Kiehl, J. T., Large, W. G., McKenna, D. S., Santer, B. D., and Smith, R. D.: The community climate system model version 3 (CCSM3), J. Climate, 19, 2122-2143, 2006.

Cramer, W., Bondeau, A., Woodward, F. I., Prentice, I. C., Betts, R. A., Brovkin, V., Cox, P. M., Fisher, V., Foley, J. A., Friend, A. D., Kucharik, C., Lomas, M. R., Ramankutty, N., Sitch, S., Smith, B., White, A., and Young-Molling, C.: Global response of terrestrial ecosystem structure and function to $\mathrm{CO}_{2}$ and climate change: results from six dynamic global vegetation models, Global Change Biol., 7, 357-373, 2001.

de Graaff, M.-A., van Groenigen, K.-J., Six, J., Hungate, B., and van Kessel, C.: Interactions between plant growth and soil nutrient cycling under elevated $\mathrm{CO}_{2}$ : A meta-analysis, Global Change Biol., 12, 2077-2091, doi:10.1111/j.1365-2486.2006.01240.x, 2006.

Denman, K. L., Brasseur, G., Chidthaisong, A., Ciais, P., Cox, P. M., Dickinson, R. E., Hauglustaine, D., Heinze, C., Holland, E., Jacob, D., Lohmann, U., Ramachandran, S., da Silva Dias, P. L., Wofsy, S. C., and Zhang, X.: Couplings between changes in the climate system and biogeochemistry, in: Climate Change 2007: The Physical Science Basis, edited by: Solomon, S., Qin, D., Manning, M., Chen, Z., Marquis, M., Averyt, K. B., Tignor, M., and Miller, H. L., Cambridge University Press, Cambridge, United Kingdon and New York, NY, USA, 499-588, 2007.

Dickinson, R. E., Oleson, K. W., Bonan, G. B., Hoffman, F. M., Thornton, P., Vertenstein, M., Yang, Z.-L., and Zeng, X.: The community land model and its climate statistics as a component of the Community Climate System Model, J. Climate, 19, 23022324, 2006.

Doney, S. C., Lindsay, K., and Moore, J. K.: Global ocean carbon cycle modeling, in: Ocean biogeochemistry: A JGOFS synthesis, edited by: Fashom, M., Springer-Verlag, New York, 217238, 2003.

Doney, S. C., Lindsay, K., Caldeira, K., Campin, J.-M., Drange, H., Dutay, J.-C., Follows, M., Gao, Y., Gnanadesikan, A., Gruber, N., Ishida, A., Joos, F., Madec, G., Maier-Reimer, E., Marshall, J. C., Matear, R. J., Monfray, P., Mouchet, A., Najjar, R., Orr, J. C., Plattner, G.-K., Sarmiento, J., Schlitzer, R., Slater, R., Totterdell, I. J., Weirig, M.-F., Yamanaka, Y., and Yool, A.: Evaluating global ocean carbon models: The importance of realistic physics, Global Biogeochem. Cy., 18, GB3017, doi:10.1029/2003GB002150, 2004.

Doney, S. C., Lindsay, K., Fung, I., and John, J.: Natural variability in a stable, 1000-yr global coupled climate-carbon cycle simulation, J. Climate, 19, 3033-3054, 2006.

Dutay, J.-C., Bullister, J. L., Doney, S. C., Orr, J. C., Najjar, R., Caldeira, K., Champin, J.-M., Drange, H., Follows, M., Gao, Y., Gruber, N., Hecht, M. W., Ishida, A., Joos, F., Lindsay, K., Madec, G., Maier-Reimer, E., Marshall, J. C., Matear, R. J., 
Monfray, P., Plattner, G.-K., Sarmiento, J., Schlitzer, R., Slater, R., Totterdell, I. J., Weirig, M.-F., Yamanaka, Y., and Yool, A.: Evaluation of ocean model ventilation with cfc-11: Comparison of 13 global ocean models, Ocean Model., 4, 89-120, 2002.

Elser, J. J., Bracken, M. E. S., Cleland, E. E., Gruner, D. S., Harpole, W. S., Hillebrand, H., Ngai, J. T., Seabloom, E. W., Shurin, J. B., and Smith, J. E.: Global analysis of nitrogen and phosphorus limitation of primary producers in freshwater, marine, and terrestrial ecosystems, Ecol. Lett., 10, 1135-1142, doi:10.1111/j.14610248.2007.01113.x, 2007.

Finzi, A. C., Norby, R. J., Calfapietra, C., Gallet-Budynek, A., Gielen, B., Holmes, W. E., Hoosbeek, M. R., Iversen, C. M., Jackson, R. B., Kubiske, M. E., Ledford, J., Liberloo, M., Oren, R., Polle, A., Pritchard, S., Zak, D. R., Schlesinger, W. H., and Ceulemans, R.: Increases in nitrogen uptake rather than nitrogenuse efficiency support higher rates of temperate forest productivity under elevated $\mathrm{CO}_{2}$, P. Natl. Acad. Sci., 104, 14014-14019, 2007.

Friedlingstein, P., Dufresne, J.-L., Cox, P. M., and Rayner, P.: How positive is the feedback between climate change and the carbon cycle?, Tellus, 55B, 692-700, 2003.

Friedlingstein, P., Cox, P., Betts, R. A., Bopp, L., von Bloh, W., Brovkin, V., Cadule, P., Doney, S., Eby, M., Fung, I., Bala, G., John, J., Jones, C., Joos, F., Kato, T., Kawamiya, M., Knorr, W., Lindsay, K., Matthews, H. D., Raddatz, T., Rayner, P., Reick, C., Roeckner, E., Schnitzler, K.-G., Schnur, R., Strassmann, K., Weaver, A. J., Yoshikawa, C., and Zeng, N.: Climate-carbon cycle feedback analysis: Results from the $\mathrm{C}^{4} \mathrm{MIP}$ model intercomparison, J. Climate, 19, 3337-3353, 2006.

Fung, I. Y., Doney, S. C., Lindsay, K., and John, J.: Evolution of carbon sinks in a changing climate, P. Natl. Acad. Sci., 102, 1120111206, 2005.

Gill, R. A., Anderson, L. J., Polley, H. W., Johnson, H. B., and Jackson, R. B.: Potential nitrogen constraints on soil carbon sequestration under low and elevated atmospheric $\mathrm{CO}_{2}$, Ecology, 87, 41-52, 2006.

Goldewijk, K.: Estimating global land use change over the past 300 years: The HYDE database, Global Biogeochem. Cy., 15, 417434, 2001

Goodale, C. L. and Aber, J. D.: The long-term effects of land-use history on nitrogen cycling in northern hardwood forests, Ecol. Appl., 11, 253-267, 2001.

Horowitz, L. W., Walters, S., Mauzerall, D. L., Emmons, L. K., Rasch, P. J., Granier, C., Tie, X. X., Lamarque, J.-F., Schultz, M. G., Tyndall, G. S., Orlando, J. J., and Brasseur, G. P.: A global simulation of tropospheric ozone and related tracers: Description and evaluation of MOZART, version 2, J. Geophys. Res., 108(D24), 4784, doi:4710.1029/2002JD002853, 2003.

Houlton, B. Z., Wang, Y. P., Vitousek, P. M., and Field, C. B.: A unifying framework for dinitrogen fixation in the terrestrial biosphere, Nature, 454, 327-330, 2008.

Hungate, B. A., Dukes, J. S., Shaw, R., Luo, Y., and Field, C. B.: Nitrogen and climate change, Science, 302, 1512-1513, 2003.

Hurtt, G. C., Frolking, S., Fearon, M. G., Moore III, B., Shevliakova, E., Malyshev, S., Pacala, S. W., and Houghton, R. A.: The underpinnings of land-use history: three centuries of global gridded land-use transitions, wood harvest activity, and resulting secondary lands, Global Change Biol., 12, 1-22, 2006.

Key, R. M., Kozyr, A., Sabine, C. L., Lee, K., Wanninkhof, J. L.,
Bullister, J. L., Feely, R. A. M., Mordy, C., and Peng, T. H.: A global ocean carbon climatology: Results from global data analysis project (GLODAP), Global Biogeochem. Cy., 18, GB4031, doi:10.1029/2004GB002247, 2004.

Lamarque, J. F., Kiehl, J., Brasseur, G., Butler, T., Cameron-Smith, P., Collins, W. D., Collins, W. J., Granier, C., Hauglustaine, D., Hess, P., Holland, E., Horowitz, L., Lawrence, M., McKenna, D., Merilees, P., Prather, M., Rasch, P., Rotman, D., Shindell, D., and Thornton, P.: Assessing future nitrogen deposition and carbon cycle feedbacks using a multi-model approach: Analysis of nitrogen deposition, J. Geophys. Res., 110, D19303, doi:10.1029/2005JD005825, 2005.

Large, W. G. and Yeager, S. G.: Diurnal to decadal global forcing for ocean and sea-ice models: The data sets and flux climatologies, National Center for Atmospheric Research, Boulder, CONCAR/TN-460+STR, 2004.

Law, B. E., Falge, E., Gu, L., Baldocchi, D. D., Bakwin, P., Berbigier, P., Davis, K., Dolman, A. J., Falk, M., Fuentes, J. D., Goldstein, A., Granier, A., Grelle, A., Hollinger, D., Janssens, I. A., Jarvis, P., Jensen, N. O., Katul, G., Mahli, Y., Matteucci, G., Meyers, T., Monson, R., Munger, W., Oechel, W., Olson, R., Pilegaard, K., Paw, U. K. T., Thorgeirsson, H., Valentini, R., Verma, S., Vesala, T., Wilson, K., and Wofsy, S.: Environmental controls over carbon dioxide and water vapor exchange of terrestrial vegetation, Agr. Forest Meteorol., 113, 97-120, 2002.

Lawrence, D. M., Thornton, P. E., Oleson, K. W., and Bonan, G. B.: The partitioning of evapotranspiration into transpiration, soil evaporation, and canopy evaporation in a GCM: Impacts on landatmosphere interaction, J. Hydrometeorol., 8, 862-880, 2007.

LeBauer, D. S. and Treseder, K. K.: Nitrogen limitation of net primary productivity in terrestrial ecosystems is globally distributed, Ecology, 89, 371-379, 2008.

Luo, Y., Su, B., Currie, W. S., Dukes, J. S., Finzi, A. C., Hartwig, U., Hungate, B. A., McMurtrie, R. E., Oren, R., Parton, W. J., Pataki, D. E., Shaw, M. R., Zak, D. R., and Field, C. B.: Progressive nitrogen limitation of ecosystem responses to rising atmospheric carbon dioxide, Bioscience, 54, 731-739, 2004.

Luo, Y., Hui, D., and Zhang, D.: Elevated $\mathrm{CO}_{2}$ stimulates net accumulations of carbon and nitrogen in land ecosystems: A metaanalysis, Ecology, 87, 53-63, 2006.

Mäkipää, R., Karjalainen, T., Pussinen, A., and Kellomäki, S.: Effects of climate change and nitrogen deposition on the carbon sequestration of a forest ecosystem in the boreal zone, Can. J. Forest Res., 29, 1490-1501, 1999.

Matsumoto, K., Sarmiento, J. L., Key, R. M., Bullister, J. L., Caldeira, K., Campin, J.-M., Doney, S. C., Drange, H., Dutay, J.-C., Follows, M., Gao, Y., Gnanadesikan, A., Gruber, N., Ishida, A., Joos, F., Lindsay, K., Maier-Reimer, E., Marshall, J. C., Matear, R. J., Monfray, P., Najjar, R., Platter, G.-K., Schlitzer, R., Slater, R., Swathi, P. S., Totterdell, I. J., Weirig, M.-F., Yamanaka, Y., Yool, A., and Orr, J. C.: Evaluation of ocean carbon cycle models with data-based metrics, Geophys. Res. Lett., 31, L07303, doi:10.1029/2003GL018970, 2004.

Matthews, H. D., Eby, M., Ewen, T., Friedlingstein, P., and Hawkins, B. J.: What determines the magnitude of carbon cycle-climate feedbacks?, Global Biogeochem. Cy., 21, GB2012, doi:10.1029/2006GB002733, 2007.

McGuire, A. D., Clein, J. S., Melillo, J. M., Kicklighter, D. W., Meier, R. A., Vorosmarty, C. J., and Serreze, M. C.: Modelling 
carbon responses of tundra ecosystems to historical and projected climate: Sensitivity of pan-arctic carbon storage to temporal and spatial variation in climate, Global Change Biol., 6 (Suppl. 1), 141-159, 2000.

McGuire, A. D., Sitch, S., Clein, J. S., Dargaville, R., Esser, G., Foley, J., Heimann, M., Joos, F., Kaplan, J., Kicklighter, D. W., Meier, R. A., Melillo, J. M., Moore III, B., Prentice, I. C., Ramankutty, N., Reichenau, T., Schloss, A., Tian, H., Williams, L. J., and Wittenberg, U.: Carbon balance of the terrestrial biosphere in the twentieth century: Analyses of $\mathrm{CO}_{2}$, climate and land use effects with four process-based ecosystem models, Global Biogeochem. Cy., 15, 183-206, 2001.

Meehl, G. A., Washington, W. M., Santer, B. D., Collins, W. D., Arblaster, J. M., Hu, A., Lawrence, D. M., Teng, H., Buja, L. E., and Strand, W. G.: Climate change projections for the twentyfirst century and climate change commitment in the CCSM3, J. Climate, 19, 2597-2616, 2006.

Meehl, G. A., Stocker, T. F., Collins, W. D., Friedlingstein, P., Gaye, A. T., Gregory, J. M., Kitoh, A., Knutti, R., Murphy, J. M., Noda, A., Raper, S. C. B., Watterson, I. G., Weaver, A. J., and Zhao, Z.C.: Global climate projections, in: Climate Change 2007: The physical science basis. Contribution of working group I to the fourth assessment report of the intergovernmental panel on climate change, edited by: Solomon, S., Qin, D., Manning, M., Chen, Z., Marquis, M., Averyt, K. B., Tignor, M., and Miller, H. L., Cambridge University Press, Cambridge, UK and New York, NY, U.S.A, 747-846, 2007.

Melillo, J. M., Steudler, P. A., Aber, J. D., Newkirk, K., Lux, H., Bowles, F. P., Catricala, C., Magill, A., Ahrens, T., and Morrisseau, S.: Soil warming and carbon-cycle feedbacks to the climate system, Science, 298, 2173-2176, 2002.

Moore, J. K., Doney, S. C., Kleypas, J. C., Glover, D. M., and Fung, I. Y.: An intermediate complexity marine ecosystem model for the global domain, Deep-Sea Res. Pt. II, 49, 403-462, 2002.

Moore, J. K., Doney, S. C., and Lindsay, K.: Upper ocean ecosystem dynamics and iron cycling in a global threedimensional model, Global Biogeochem. Cy., 18, GB4028, doi:10.1029/2004GB002220, 2004.

Nadelhoffer, K. J., Emmett, B. A., Gunderson, P., Kjønaas, O. J., Koopmans, C. J., Schleppi, P., Tietema, A., and Wright, R. F.: Nitrogen deposition makes a minor contribution to carbon sequestration in temperate forests, Nature, 398, 145-148, 1999.

Nadelhoffer, K. J., Colman, B. P., Currie, W. S., Magill, A., and Aber, J. D.: Decadal-scale fates of ${ }^{15} \mathrm{~N}$ tracers added to oak and pine stands under ambient and elevated $\mathrm{n}$ inputs at the Harvard Forest (USA), Forest Ecol. Manag.t, 196, 89-107, 2004.

Nakicenovic, N. and Swart, R.: Special report on emissions scenarios, in: Cambridge University Press, Cambridge, UK, 612, 2000.

Norby, R. J. and Iversen, C. M.: Nitrogen uptake, distribution, turnover, and efficiency of use in a $\mathrm{CO}_{2}$-enriched sweetgum forest, Ecology, 87, 5-14, 2006.

Oleson, K. W., Dai, Y., Bonan, G. B., Bosilovich, M., Dickinson, R. E., Dirmeyer, P., Hoffmann, F., Houser, P., Levis, S., Niu, G.-Y., Thornton, P., Vertenstein, M., Yang, Z.-L., and Zeng, X.: Technical description of the Community Land Model (CLM), NCAR, Boulder, NCAR Tech Note NCARTN-461+STR, 174, 2004.

Ollinger, S. V., Aber, J. D., Reich, P. B., and Freuder, R. J.: Interactive effects of nitrogen deposition, tropospheric ozone, elevated $\mathrm{CO}_{2}$ and land use history on the carbon dynamics of northern hardwood forests, Global Change Biol., 8, 545-562, 2002.

Pacala, S. W., Hurrt, G. C., Baker, D., Peylin, P., Houghton, R. A., Birdsey, R. A., Heath, L., Sundquist, E. T., Stallard, R. F., Ciais, P., Moorcroft, P., Casperson, J. P., Shevliakova, E., Moore, B., Kohlmaier, G., Holland, E., Gloor, M., Harmon, M. E., Fan, S.-M., Sarmiento, J. L., Goodale, C. L., Schimel, D., and Field, C. B.: Consistent land- and atmosphere-based US carbon sink estimates, Science, 292, 2316-2320, 2001.

Peters, W., Miller, J. B., Whitaker, J., Denning, A. S., Hirsch, A., Krol, M. C., Zupanski, D., Bruhwiler, L., and Tans, P. P.: An ensemble data assimilation system to estimate $\mathrm{CO}_{2}$ surface fluxes from atmospheric trace gas observations, J. Geophys. Res., 110, D24304, doi:10.1029/2005JD006157, 2005.

Ramankutty, N. and Foley, J. A.: Estimating historical changes in global land cover: Croplands from 1700-1992, Global Biogeochem. Cy., 13, 997-1027, 1999.

Randerson, J. T., Hoffman, F. M., Thornton, P. E., Mahowald, N. M., Lindsay, K., Lee, Y.-H., Nevison, C. D., Doney, S. C., Bonan, G., Stöckli, R., Covey, C., Running, S. W., and Fung, I. Y.: Systematic assessment of terrestrial biogeochemistry in coupled climate-carbon models, Global Change Biol., 15, 2462-2484, doi: 10.1111/j.1365-2486.2009.01912.x, 2009.

Raupach, M. R., Canadell, J. G., and Le Quéré, C.: Anthropogenic and biophysical contributions to increasing atmospheric $\mathrm{CO}_{2}$ growth rate and airborne fraction, Biogeosciences, 5, 16011613, 2008, http://www.biogeosciences.net/5/1601/2008/.

Reich, P. B., Hobbie, S. E., Lee, T., Ellsworth, D. S., West, J. B., Tilman, D., Knops, J. M. H., Naeem, S., and Trost, J.: Nitrogen limitation constrains sustainability of ecosystem response to $\mathrm{CO}_{2}$, Nature, 440, 922-925, 2006.

Sabine, C. L., Feely, R. A., Gruber, N., Key, R. M., Lee, K., Bullister, J. L., Wanninkhof, J. L., Wong, C. S., Wallace, D. W. R., Tilbrook, B., Millero, F. J., Peng, T.-H., Kozyr, A., Ono, T., and Rios, A. F.: The oceanic sink for anthropogenic $\mathrm{CO}_{2}$, Science, 305, 367-371, 2004.

Schlesinger, W. H.: On the fate of anthropogenic nitrogen, P. Natl. Acad. Sci., 106, 203-208, 2009.

Sokolov, A. P., Kicklighter, D. W., Melillo, J. M., Felzer, B. S., Schlosser, C. A., and Cronin, T. W.: Consequences of considering carbon-nitrogen interactions on the feedbacks between climate and the terrestrial carbon cycle, J. Climate, 21, 3776-3796, doi:10.1175/2008JCLI2038.1, 2008.

Stephens, B. B., Gurney, K. R., Tans, P. P., Sweeney, C., Peters, W., Bruhwiler, L., Ciais, P., Ramonet, M., Bousquet, P., Nakazawa, T., Aoki, S., Machida, T., Inoue, G., Vinnichenko, N., Lloyd, J., Jordan, A., Heimann, M., Shibistova, O., Langenfelds, R. L., Steele, L. P., Francey, R. J., and Denning, A. S.: Weak northern and strong tropical land carbon uptake from vertical profiles of atmospheric $\mathrm{CO}_{2}$, Science, 316, 1732-1735, doi:10.1126/science.1137004, 2007.

Stieglitz, M., McKane, R. B., and Klausmeier, C. A.: A simple model for analyzing climatic effects on terrestrial carbon and nitrogen dynamics: An arctic case study, Global Biogeochem. Cy., 20, GB3016, doi:10.1029/2005GB002603, 2006.

Suding, K. N., Collins, S. L., Gough, L., Clark, C., Cleland, E. E., Gross, K. L., Milchunas, D. G., and Pennings, S.: Functional- and abundance-based mechanisms explain diversity loss due to N fertilization, P. Natl. Acad. Sci., 102, 4387-4392, doi:10.1073/pnas.0408648102, 2005. 
Thornton, P. E., Law, B. E., Gholz, H. L., Clark, K. L., Falge, E., Ellsworth, D. S., Goldstein, A. H., Monson, R. K., Hollinger, D., Falk, M., Chen, J., and Sparks, J. P.: Modeling and measuring the effects of disturbance history and climate on carbon and water budgets in evergreen needleleaf forests, Agr. Forest Meteorol., 113, 185-222, 2002.

Thornton, P. E. and Rosenbloom, N. A.: Ecosystem model spin-up: Estimating steady state conditions in a coupled terrestrial carbon and nitrogen cycle model, Ecol. Model., 189, 25-48, 2005.

Thornton, P. E., Lamarque, J.-F., Rosenbloom, N. A., and Mahowald, N. M.: Influence of carbon-nitrogen cycle coupling on land model response to $\mathrm{CO}_{2}$ fertilization and climate variability, Global Biogeochem. Cy., 21, GB4018, doi:10.1029/2006GB002868, 2007.

Thornton, P. E. and Zimmermann, N. E.: An improved canopy integration scheme for a land surface model with prognostic canopy structure, J. Climate, 20, 3902-3923, doi:10.1175/JCLI4222.1, 2007. van Groenigen, K.-J., Six, J., Hungate, B. A., de Graaff, M. A., van Breemen, N., and van Kessel, C.: Element interactions limit soil carbon storage, P. Natl. Acad. Sci., 103, 6571-6574, 2006.

Vitousek, P. M. and Howarth, R. W.: Nitrogen limitation on land and in the sea: How can it occur?, Biogeochemistry, 13, 87-115, 1991.

Wang, Y. P., Houlton, B., and Field, C. B.: A model of biogeochemical cycles of carbon, nitrogen and phosphorus including symbiotic nitrogen fixation and phosphatase production, Global Biogeochem. Cy., 21, GB1018, doi:10.1029/2006GB002797, 2007.

Washington, W. M., Weatherly, J. W., Meehl, G. A., Semtner, A. J., Bettge, T. W., Craig, A. P., Strand Jr., W. G., Arblaster, J., Wayland, V. B., James, R., and Zhang, Y.: Parallel climate model (PCM) control and transient simulations, Clim. Dynam., 16, 755-774, 2000.

Yeager, S. G., Shields, C. A., Large, W. G., and Hack, J. J.: The low-resolution CCSM3, J. Climate, 21, 2545-2566, 2006. 